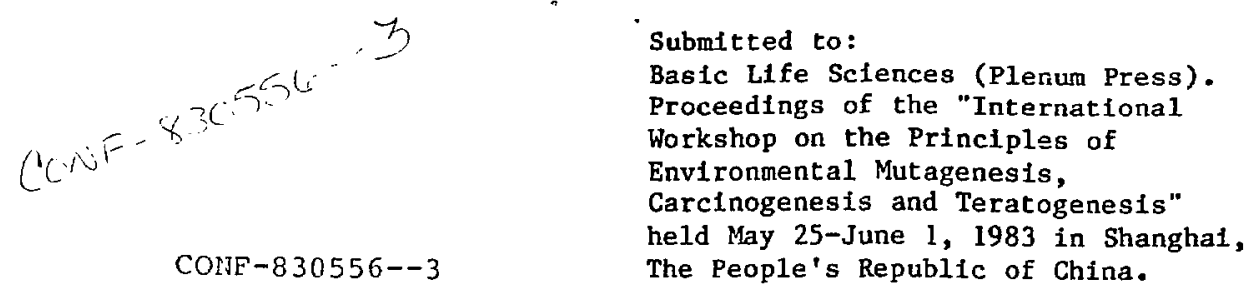

DE84 003485

\title{
GERM CELL TOXICITY: SIGNIFICANCE IN GENETIC AND FERTILITY EFFECTS OF RADIATION AND CHEMICALS
}

E. F. Oakberg

Blology Division, Oak Ridge National Laboratory, Oak Ridge, TN 37830

\section{DISCLAIMER}

\begin{abstract}
This report was prepared as an account of work sponsored by an agency of the United States Government. Neither the United States Government nor any agency thereof, nor any of their employees, makes any warranty, express or implied, or assumes any legal liability or responsibility for the accuracy, completeness, or usefulness of any informicion, apparatus, product, or process disclosed, or represents that its use would not infringe privately owned rights. Reference herein to any specific commercial product, process, or service by trade name, trademark, manufacturer, or otherwise does not necessarily constitute or imply its endorsement, recommendation, or favoring by the United States Government or any agency thereof. The views and opinions of authors expressed herein do not mecessarily state or reflect those of the Inited States Government or any agency thereof.
\end{abstract}

By acceptance of this article, the publisher or reclpient acknowledges the U.S. Government's right to retain a nonexclusive, royalty-free license in and to any copyright covering the article.

Research sponsored by thie Office of Health and Environmental Research, U.S. Department of Energy under contract W-7405-eng-26 with the Union Carbide Corporation. 


\section{SUMMARY}

The primordial germ cells originate in the region of the caudal end of the primitive streak, root of the allantois, and yolk sac splanchuopleure, and migrate to the gonadal ridges where they divide to form the oogonia of the female and gonocytes of the male. In the female, the transition to oocytes occurs in utero, and the female mammal is born with a finite number of oocytes that cannot be replaced. By contrast, the gonocytes of the male Intiate divisions soon after birth to form the spermatogonial sten cells, which persist throughout reproductive $11 \mathrm{fe}$ of the male and are capable of regenerating the seminiferous epithelium after lijury. As a result of these basic differences in gametogenesis, the response of the male and female to radiation and chemicals is different. Any loss of oocytes in the female cannot be replaced, and if severe enough, will result in a shortening of the reproductive span. In the male, a temporary sterile period may be induced owing to destruction of the differentiating spermatogonia, but the stem cells are the most resistant spermatogonial type, are capable of repopulating the seminiferous ept thelium, and fertility usually returns. The response of both the male and female changes with development of the embryonic to the adult gonad, and with differ entiation and maturation in the adult. The primordial germ cells, early oocytes, and differentiating spermatogonia of the adult male are unusually sensitive to the cytotoxic action of noxious agents, but each agent elicits a specific response oring to the intricate biochemical and physiological changes associated with development and maturation of the gametes. The relationship of germ cell killing to fertility is direct, and long-term fertility effects can be predicted from histological analysis of 
3

the gonads. The relationship to genetic effects on the other hand, is Indirect, and acts primarily by limiting the cell stages available for testing, by affecting the distribution of mitotically active stem cells among the different stages of the mitotic cycle, and thereby, changing both the type and frequency of genetic effects observed. 


\section{INTRODUCT ION}

The level of our understanding of the effect of radiation, chemicals, pollutants, and noxious agents in general on the gonads, and the relationship of these effects to fertility and to transmission of genetic damage is dependent upon our understanding of the normal process of germ cell development. Some of the problems to be discussed here were phrased over a century ago, but it is only within the last thirty years that the direct lineage between primordial germ cells and the definitive gametes has been firmly established, and significant progress in describing spermatogonial stem cell renewal has come only within the last twelve years. On the basis of these advances, much progress has been made in characterizing the response of the different stages of gametogenesis, and in applylng these data to an understanding of the hazards of radiation and chemical exposure on fertility and possible genetic damage. Many questions concerning normal germ cell development remaln, however, and we also are woefully 1gnorant of the. baslc mechanisms involved in mutagenic and cytotoxic action of radiation and chemicals.

\section{Normal gametogenesis: male}

The primordial germ cells orfginate in the region of the caudal end of the primitive streak, root of the allantolc mesoderi, and yolk sac splanchuopleure. From there, they migrate to the germinal ridges by route of the dorsal mesentery $(12,19,60,99)$. Mitotic division occurs both during migration of the germ cells, and after they reach the germinal ridges. The Inttal stages are the same in both sexes, but diverge at about 12-13 days In the mouse, when testis and ovary can be distinguished morphologically (60). Mitotic activity of the gonocytes decreases at 14-18 days in the 
male and only rare cells are indiviston at birth $(3,60)$. DNA synthesis beglns in the first few hours after birth (75), the definitive sten cell population and differentiating spermatogonia appear, and the entire process of spermatogenesis is initiated $(75,93)$. As spermatogonia differentiate

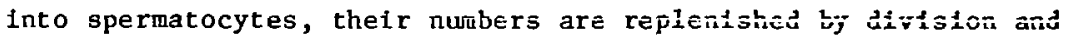
differentiation of the stem cells through the process terned stem cell renewal.

The problem of Identification of the stem cell and description of stem cell renewal has had a long history, for it was recognized by Benda over a century ago that the continued production of spermatozoa over the reproductive $11 \mathrm{fe}$ of a male mamal required continuous renewal of the spermatogonial population (4). The spermatogonla were first described by LaValette (51), and Regaud (84) was the first to recognize that the A spermatogonia were the most primitive cell type of the seminiferous epithelium, a conclusion which was supported by subsequent experiments with radiation (85). For excellent revilews of the literature prior to 1965, see Hennah-Alava (40), Clermont (13) and Roosen-Runge (87). Classiflcation of stages of the cycle of the seminiferous epithellum by the technique of Leblond and Clemont (52) led to the Identification of 4 classes of type A spermatogonla by Monesi (61), and a 5 th class was identified by the study of segments of seminfferous tubules mounted in toto (14). A meticulous study of tubule whole mounts in the rat (42), a similar study in the mouse (86) and long-term ${ }^{3} \mathrm{H}$-thymidine labeling in the mouse (71) demonstrated that this 5 th class of spermatogonia, given the term $A_{0}$ by clermont and Bustos-obregon (14), actually are the active sten cells of the testis $(42,46,71,86)$, and maintain their own numbers by the process of division 
and also replenish the generations of differentiating spermatogonia. These cells have been given the term $A_{s}$ (A stem, A single) to describe both their stem cell role, and their occurrence as single, isolated cells in the tubule (79).

In whole-mounts, the interphase nucleus of the stem cells is small (Figs. 2,4), ovold or spherical in shape, with heterogeneous finely granular chromatin and an inconsplcuous nucleolus (42). They sometimes have an irregular, lobed nucleus suggestive of cells with aneboid properties. In sections they have an oval, darkly-staining nucleus with granular chromatin and an Indistinct nucleolus (71) (Figs. 5,6). A study of their cell-cycle properties revealed at least two populations of $A_{S}$ spernatogonia in the rat, one with a cell-cycle time of about 50 hours, and a second, long-cycling population that could have a cell-aycle time as long as 13 days (43). Labeling with ${ }^{3} \mathrm{H}$-thymidine demonstrated that these cells eventually divide and form Labeled daughter cells. A comparable analysis has not been made in the mouse, but heavily labeled $A_{g}$ (Fig. 8) spermatogonia are frequently observed 207 hours (one cycle of the semintferous epithelium) after ${ }^{3} \mathrm{H}-\mathrm{TdR}$ labeling, and these cells also divide (Fig. 9) to form both labeled $A_{s}$ and $A_{p r}$ (Fig. 10) spermatogonia (71,73, 79). The above observations, both in the rat and mouse, are positive proof both of the long-cycling property of $A_{s}$ spermatogonia and their active stem-cell role. The initial step in differentiation is not known, but the formation of a pair of cells connected by a cytoplasmic bridge appears to be an Irreversible step toward the production of spermatozoa (45). However, since both slow and fast-cycling $A_{s}, A_{p r}$, and $A_{a 1}$ spermatogonia all have the same nuclear morphology, positive proof that only the 
long-cycling $A_{B}$ spermatogonia have a stem-cell role has not yet been possible.

On the basis of the above studies on the sten cells, Huckins $(42,44)$ and Dakberg and Huckins (79) have proposed the model of stem cell renewal shown in Figure 1. The $A_{s}$ (Figs. 2,5) spermatogonia can divide to form more $A_{s}$ cells, or, cytokinesis can be incomplete, forming a pair of cells $\left(\mathrm{A}_{\mathrm{pr}}\right)$ (Figs. $\left.3,4,10\right)$ connected by a cytoplasmic bridge. With subsequent division, groups of connected $A_{a l}$ cells $2^{n}$ in number are formed, still with the nuclear morphology of the $A_{p r}$ and $A_{s}$. Collectively, these all are referred to as "undifferentlated" type A spermatogonia because of their similar nuclear morphology (44), but formation of the pair probably is the Initial step In an irreversible developmental sequence. The $A_{a l}$ in stages 5,6 , and 1 transform into $A_{1}$ (Figs. 11,16,17) spermatogonia which divide at the end of stage 1 to form $A_{2}$ (Figs. 12,18), with subsequent divisions giving rise to $\mathrm{A}_{3}$ (Figs. 13,19), $\mathrm{A}_{4}$ (Figs. 14,20) In (Figs. 15,21) and B (Figs. 16,22) spermatogonia. The B spermatogonia divide to form preleptotene spermatocytes (Fig. 11) which enter DHA synthesis in stage 1 and begin the long meiotic prophase which culminates in the meiotic divisions in stage 3 with formation of spermatids. Although the above description is specific for the rat and mouse, the basic principles apply to all mamals, and probably most members of the animal kingdom (40), with specles specific morphology of the type A spertuatogonia and late spermatids. B spermatogonia, primary spermatocytes, the meiotic divisions, and early spermatid stages have similar morphology in all mammals.

The development of the different cell types is closely synchronized, and gives rise to the characteristic cellular associations represented by 
regions of the tubules which are in different stages of development. The complete series of tubule stages constitutes one cycle oi the seminiferous epithelium. On the basis of the acrosome development in spermatids, Leblond and Clermont (52) described 14 stages in the cycle of the seminiferous epithelium of the rat, and Oakberg (66) described 12 in the mouse. Arrangement of the stages on the basis of acrosome development automatically reveals the developmental sequence of differentiating spermatogonia and spermatocytes. Not only the cell type, but the number of cells in any given stage can be predicted, and comparison of counts in control and treated animals is used in assessing the effects of cytotoxic agents $(65,66,73,78,79)$. However, only 6 stages of the cycle, Identifiable on the basis of the 6 generations of differentiating spermatogonia, can be recognized in whole mounts. For this reason, Oakberg and Huckins (79) proposed the classification given in Table 1. The spermatogonia characteristic of these stages are represented in Figures 11-16 for whole-mounts, and in Figures 17-22 for sections.

The concept of a spermatogendc wave progressing along the tubule was proposed early in the study of the testis $(4,18,84)$, but irregularties such as reversal of the progression of stages makes 1 t more practical to think of the succession of stages in the dimensic of time, 1.e., a given spot in the tubule will pass through all stages in the eycle of the seminiferous eptthelium during a time interval which is a constant for the spectes. This is $\sim 207$ hours in the mouse, 13 days in the rat (depending upon strain) and 16 days in man. Four complete cycles of the seminiferous epithelium are required for development of the $A_{1}$ spermatogonia of mouse and rat into mature spermatids in the testis $(52,66)$. At least one 
additional cycle is required for development of $A_{s}$ into $A_{1}$ spermatogonia, so the duration of sperinatogenesis $15 \sim 43$ days in the mouse, 65 days 1n the rat, and $\sim 90$ days in man. Study of the cellular assoctations after

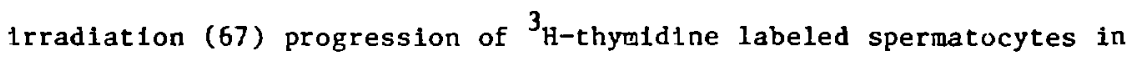
Irradiated testes (20), and after 6-mercaptopurine injection (76), and endocrinological studies (15) all indicate that the rate of spermatogenesis is a species constant that is not affected by experimental procedures. There is evidence, however, that spermatogonial development proceeds more rapidly in the juvenile animal (41).

Once the cellular associations were described and the duration of the cycle of the semfiferous epithelium determined, it was obvious that Information on the duration of each stage of the cycle would allow observation of effects on selected cell types at any desired stage of subsequent development. For this purpose, the 207 hour duration of the cycle was apportioned among the 12 stages in the basis of the frequency distribution of a sample of 200 randomly selected tubule cross sections from each of 12 control mice (67), and in a later study, of 16 control mice for the frequency distribution of the six stages described by Oakberg and Huckins (79) (Table 1). From this, the times required for each cell stage to develop into mature spermatids and be released from the tubule was calculated (Table 2). The seven days required for transit frotn test is to ejaculate (78) was added to these estimates to give the time at which specific stages are available for fertilization. It is clear that all stages except the stem cell have short lives in comparison to the total reproductive span, and the ster cell therefore is the single most important 
cell type in both reproductive and genetic effects of radiation and chemicals in males.

Radiation response

Prenatal and neonatal. The Immature rat testis has three periods of high sensitivity to radiation-induced sterility. The first, in the 13.5-17.5 day embryo, is assoctated with high mitotic activity of the primordial germ cells, and is common to both sexes $(2,55)$. The second, and most sensitive period in the male occurs during the period of low mitotic activity of the germ cells just before birth unt 112 days postpartum in the rat (2). The Induced sterility can be traced to killing of germ cells and resulting deficlency of spermatogonia in the adult. Resistance increases as the first type A spermatogonia appear, but a third period of sensitivity occurs at 17 days. A similar response occurs in the mouse, but at slightly younger ages. In contrast to the rat, the newborn mouse is not sterilized by doses of several hundred rads (94). Comparable Information is not avallable for other species, including man, but similar patterns of response are likely to occur and particular care should be taken to avoid radiation exposure of the fetal, neonatal, and juvenile testis.

\section{Adult}

Males are initially fertile after acute radiation exposure owing to continued development of cells irradiated as spermatozoa, spermatids, and spermatocytes $(72,85)$. A period of temporary infertility then ensues with doses of 20-300 $\mathrm{k}$ depending upon genetic strain and species, and fertility usually returns as surviving stem cells repopulate the seminiferous epithelium. The dose of $20 \mathrm{R}$ is for man, and is not based on demonstrated 
lack of fertility, but is a result anticlpated from the known effect of small acute radiation exposure on sperm count in men (88). The ster1le period is of longer duration after high exposures owing to killing of spermatocytes, extensive gonial killing, induction of very high levels of dominant lethals in spermatids, and slow repopulation of the seminiferous epithelium when the number of surviving spermatogonia is low (72).

Development or spermatids is not affected by doses as high as $1500 \mathrm{R}$ in the nouse $(78), 32,000 \mathrm{R}$ or more is required to affect the motility of human sperm, and the fert1lizing capacity of rabbit sperm is normal after an exposure of $65,000 \mathrm{R}(11)$. Thus spermat1ds and spermatozoa are extremely resistant to direct effects of radiation on their development and function. They are sensitive, however, to the induction by radiation and certaln chemical mutagens of presumed point mutations, and to chromosome breakage with resultant high frequency of dominant lethality and chromosome rearrangements $(7,31)$.

Chromosome breakage in primary spernatocytes of the mouse shows the same changes $1 n$ sensitivity with melotic stage that have been observed in other specles, lncluding plants $(77,98)$. Chromosome breakage is highest in dlakines1s-metaphase I, and lowest in preleptotene and leptotene. Senstivity to cell-killing, as measured by production of spermatids, shows the reverse pattern, with diakinesis-metaphase I being the most resistant and preleptotene the most sensitive. As a result of Induced chromosome breakage, spermatids derived from spermatocytes exposed to $100 \mathrm{R}$ or more show an abnormal size distribution ranging from micronuclet to obviously polyploid nuclet owing to various levels of aneuploidy and heteroploidy $(78,85)$. 
The induction of a sterile period and subsequent recovery of fertility both arise from the spermatogonial response. This was described by Regaud and Lacassagne ( 85 ), but analysis of the response of the different spermatogonial classes became possible only after description of the cycle of the seminiferous epithelium and timing of germ cell development were available. It now has been demonstrated that the primary radiation response of the rapidly cycling $A_{s}, A_{p r}, A_{a l}$, and all differentiating spermatogonia is cell death $(61,62,65,72,73)$. Observation of ear 1 y intervals revealed a high incidence of necrotic suermatogonia at 12-18 hours $(62,65)$. Cell division is rare at this time, and study of early stages of degeneration indicated late interphase or early prophase as the stages where degeneration occurs $(62,65)$. This varies somewhat for the different generations of spermatogonia (62). With early sperinatogonia $A_{1}$, death is delayed unt $t$ the cells approach their first post-irradiation division several days later, and the long-cycling stem cells continue to degenerate up to 7 or 8 days after irradiation. In the meantime, division of surviving cells has begun, and the concurrence of continued degeneration and repopulation makes determination of the minimum numbers of surviving cells impossible. From the above, it follows that the stem cell is the most important cell type in radiation response. Other spermatogonia have short life spans, and owing to their high sensitivity to cytotoxic agents, also are likely to be eliminated by cell death.

The stem cells surviving radiatiou doses of $150 \mathrm{R}$ or more are almost exclusively from the long-cycling compartment $(46,79)$. Furthermore, cells In DNA synthesis are sensitive (73), and selective kiling restricts the survivors to a progressively narrowing segment of the cell cycle with 
increasing dose. As a result, the mitotic index is initially reduced, and initiation of recovery is delayed at high doses. The pattern of cell death In stem cells is similar for that of $A_{j}$ spermatogonia, and as a result, minimum cell count is not reached until 7 or 8 days after treatment (Table 3). This is further Indication that the cell cycle time of the stem cell approximates one cycle of the seminiferous eptthelium ( $207 \mathrm{hrs}$ ). It is of note that the effect of agents that induce slight but still definite reduction in stem cell numbers is detectable on $1 \mathrm{y}$ at $207 \mathrm{hrs.} \mathrm{after}$ treatment.

The survival curve for undifferentiated spermatogonia is smooth throughout the 100-100C $R$ range $(73,90)$ ( $F I g$. 23). The representation of different stages of the mitotic cycle among the survivors, however, is dependent both upon dose and dose-fractionation. Labeling with ${ }^{3} \mathrm{H}-\mathrm{TdR} 24$ hrs prior to irradiation suggests ccmparable percentage labeling in controls and spermatogonla p: : e 207 hrs after doses of 100-600 R. The number or labeled cells is stgnifliantly redurea below control at $1000 \mathrm{R}$, and enhanced if the dose is given in two $500 \mathrm{R}$ fractions $24 \mathrm{hrs}$ apart. Thus at the highest doses used, distribution of survivors among stages of the mitotic cycle is changed, and may be a factor in the reduced number of mutations/roentgen/locus observed with a single exposure of $1000 \mathrm{R}$, and the enhanced rate observed with the $500+500 \mathrm{R}$ dose (73). Such relationships must be accepted with caution, however, for the number of mutations is so low that it is impossible to relate them to a specific stage of the ster cell cycle. The results of labeling prior to irradiation also have signiflcant bearing on mode? 3 of stem cell renewal and repopulation after radiation-induced depletion of spermatogonia (79). 
The fact that the cells surviving radiation are capable of repopulating the seminiferous epithellum is clear demonstration of their stem cell role, and secondly, that many of them are labeled if ${ }^{3} \mathrm{H}$-thymidine is given before Irradiation is irrefutable evidence that the stem cell of the testis is in continuous cycle $(73,79)$. Furthermore, the data yield information on mitotic activity of the stem cells during repopulation. Varlous authors have suggested that stem cells enter a period of rapid division in order to replace the depleted spermatogonial populations. First of all, if this were so, one would not expect to see labeled cells 207 (Figs. 8-10) and 414 hrs after labeling (73), for label would be diluted beyond recognition by rapid divisions. Also, there is no effect of dose on percent labeled cells over the 100-600 R range, yet few stem cells are killed by 100 , and many are killed by $600 \mathrm{R}$. Finally, the relative positions of all doses except control and $500+500 R$ is maintalned from 207 to 414 hrs (73). This suggests that stem cell cycle properties have not been affected in the $0-17$ day interval, yet repopulation already has begun. All of the above considerations suggest that radiation exposure does not affect the cell cycle properties of $A_{s}$ spermatogonta. Mitotic activity of stem cells. The above conclusion is in agreement with recent data demonstrating the lack of effect of radiation on the circadian rhythm of cells in the corneal eptthelfum (89) and bone marrow (64). The effect of fractionation interval on frequency of chromosome breakage, length of stertle period, and frequency of spectfic locus mutations is more likely the result of partial synchronization of the stem cells by killing of sensitive stages of the mitotic cycle. This is supported by the fact that $75 \%$ of the cells are labeled by a single 
injection of ${ }^{3} \mathrm{H}-\mathrm{TdR} 3$ days after $150 \mathrm{R}$, and 5 days after $300 \mathrm{R}$. This suggests that mitotic activity has an oscillating pattern with time after exposure, and the effect of fractionation interval is a reflection of the response of the preponderant stage at any given interval. Eventually these oscillations are damped as the synchrony is lost and the population returns to a normal distribution among the mitotic stages. That the synchrony is lost is proof that cell cycle times are variable, and the division of the $A_{S}$ speimatogonia into only slow- and fast-cycling classes probably is an oversimplification. Differences observed with short fractionation intervals also may be influenced by either damage of repalr mechanisms of the cell, or by failure of repair before the second dose is given.

A possible complication in the study of fractionation effects could arise if mitotic activity of the stem cells had a circadian rhythm. Recently, circadian rhythas have been shown to be a significant factor in mitotic activity after irradiatton of the corneal epithelium and bone marrow $(64,89)$. Absence of a circadian rhythm in spermatogonia was reported by Bullough (9), and later we confirmed his observation (unpublished data). The procedures used, however, did not identify the stem cell. Recently we Initiated such a study in the mouse using segments of tubules mounted in toto. The highest mitotic rate of $A_{s}$ spermatogonia of $\sim 2 \%$ was observed at 10 and 11:00 a.m., but owing to high variability among mice, this was not significantly higher than the overall mean of 1.4\%. Similar results were obtalned for DNA synthesis where mice were given 3 H-TdR, Irradiated with $300 \mathrm{R}$ X-rays 24 hrs later, and kflled 207 hrs after labeling. The labeling percentages varled from 14 to $21 \%$, but did not differ from the mean of $18 \%$. Since the slides for exposure to $300 \mathbf{R}$ 
were avallable, sections were scored for effect of time of day on survival of As spermatogonia 183 hrs after irradiation. Again there was no Indication of a clrcadian rhytha, with number of stem cells per 200 tubule cross-section ranging from 33 to 41 wth a mean of 36.7 . On the basis of these resulte, it appears that the sominiferous epthellum is different from other cell-renewal tissues of the body in that mitotic activity is not Influenced by a clrcadian rhythm. Therefore, time of day can be ignored tn fractionation experiments and in the time that tissues are taken for observation. One must be aware, however, that the data on mitotic index in controls includes both slow and fast-cycling $A_{s}$ spermatogonia, and there is a possibilfty that a clrcadian rhythm in the slow-cycling cells is masked by the larger, more rapldly dividing compartment.

Stage of cycle of the seminiferous eptthelium, however, does have an effect on both mltotic tndex, where the $1.7 \%$ observed in stage 5 is significantly higher than for other stages, and in percentage of labeled cells observed 207 hrs after the combined ${ }^{3} \mathrm{H}$-TdR labeling and radiation treatment, where frequency of labeled cells is low in stages 1 and 2 of the cycle. Therefore, the common practice of selecting only certain stages of the cycle of the seniniferous eptthelium for study could lead to erroneous conclustons.

Response to chemicals. Information on the normal process of gametorenesis and the basic techniques for study of the testis are the principal carryovers from radiation work to the Investigation of the effects of chemicals. Because of the large number of chemicals tested, and the wide differences tn their response, a compıte converage of the 11terature w11 not be attempted. Instead, a few selected examples wi:1 be 
used to 11 lustrate general principles finportant in evaluating the effects of chemicals on the testis.

That cirtain chemicals are cytotoxic to tie germ cells, and can produce sterility in the male has been known since the work of Jackson and colleagues $(47,48,81)$ in the $50^{\prime} \mathrm{s}$. The action was termed radiominetic because of the Induction of temporary sterile periods with subsequent recovery, but more refined analysis show that response to radiation differed from response to chemicals and furthermore, that the response to a spectfic compound was unique $(47,48,81)$. In spite of the numerous papers published in the following 30 years, and the number of chemicals tested, this statement is st111 val1d, and we st1ll do not understand the bases for the differences in response to even closely related compounds. A comparison of the effects of some of the more thoroughly tested chemicals 1s presented in Table 4. It is clear that a11 compounds inducing mutat lons in stem ceils are cytotoxic, but that not all cytosoxic agents indice mutations 1n stem cells. Comparison with dominant lethality and heritable translocations shows the sace lack of correspondence with cytotoxic action on the undfferentiated spermatogonia. Therefore, killing of testicular cells cannot be used to predict genetic effects, but it can demonstrate the presence of cytotoxic substances even in the absence of demonstrable domfnant lethality, translocations, or gene mutations.

We have studied only two compounds in detail, 6-mercaptopurine because 1: was suggested that it may alter the rate of gametogenes is (34), and -thyl nitrosourea because of its high mutagenicity for spermatogonial stem cells (92). The result with both of these chenicals reveal how the response shifts with germ cell stage, undoubtedly in relation to changes in 
organization of the DNA and associated biochemical and phystological processes occurring during differentiation.

One-hundred fifty $\mathrm{mg} / \mathrm{kg}$ 6-mercaptopurine had no effect on undifferentiated spermatogonia $\left(A_{s}, A_{p r}, A_{a l}\right) . A_{1}$ cells were slightly reduced in numbers, but $A_{3}$ spermatogonia (counted as In and $B$ cells 72 hrs later), were reduced to $52 \%$ of control. $\mathrm{A}_{4}-\mathrm{In}$ spermatogonia, scored as preleptotene spermatocytes at $72 \mathrm{hrs,}$ showed no decrease from control, yet these cells show chromatid and iso-chromatid breaks in diakinesis at 14-15 days (34). The response obviously is changing with spermatogonial differentiation, but whot makes the $A_{3}$ gonia sensitive to immediate cell death when the precursur $A_{1}$ and $A_{2}$ gonia and the $A_{4}$, which are derived from the division of $A_{3}$, likewise shed no early cell death? Also, what is unique about the late $A_{4}$ and In cells that results in a delayed effect expressed as chromosome breakage at days 14 and 15 ? Type B spermatogonia, which are derived from the In do not show this effect (76).

It has been demonstrated repeatedly that radiation and chemicals have no effect on the rate of gametogitiesis or on minimum sperm transport time $(20,67,76)$. This is demonstrated in Figure 24 , where appearance of labeled sperm in the ejaculate is compared for males given $150 \mathrm{mg} / \mathrm{kg}$ 6-mercaptopurine and controls. Labeled sperm reached the ejaculate at the same time In both groups, confirming the conclusion of earlier workers. Labeled sperm persisted in the ejaculate for a longer time in the 6-mercaptopurine treated males, however, indicating an Increase in maximum sperm transport time, most 11kely as a result of oligospermia (76). That passage through the epldidynis and vas deferens is longer when sperm numbers are low had not previously been demonstrated, but could have been inferred from 
radiation data, where induction of a sterile period requires higher doses than would be predicted on the basis of spermatogonial kIlling. Since spermatogenesis and minimum sperm transport time are unaffected by 6-mercaptopurine, preleptotene spernatocytes, which show no detectable chromosome breakage at diakinesis-metaphase I, are nevertheless responsible for the dominant lethality observed 32.5 - 35.5 days after $150 \mathrm{mg} / \mathrm{kg}$ 6-mercaptopurine. Conversely, the chronatid and isochromatid breaks observed on day 14 apparently do not result in dominant lethalfty (76). Our previous experience with radiation response of spermatogonia was used to resolve this question. An exposure of $150 \mathrm{R}$ of $\mathrm{x}$-rays, known to be an $\mathrm{LD}_{100}$ for $\mathrm{A}_{4}-\mathrm{In}$, and $\mathrm{B}$ spermatogonia was given prior to $150 \mathrm{mg} / \mathrm{kg}$ 6-mercaptopurine, thus limiting dominant lethality to a spermatocyte response. The response was the same as observed with 6-mercaptopurine alone, demonstrating that it clearly was a preleptotene response (76). Dominant lethals were higher at 36.5 - 41.5 days in the combined treatment, most like?y as a result of the severe oligospermia induced.

The results with 6-mercaptopurine demonstrate that the response, In terms of ce11 lethality, chromosome breakage, and dominant lethality changes dramatically with progression through development of even closely related cell types. Furthermore, the minimum times estimatod for cells in the testis to complete development and to reach the ejaculate are valid; sperm transport time in the epididymis and vas deferens can be increased in treated males however, leading to a mixture of cell stages different from controls at certain intervals after treatment. Finally, tlia relationship between detectable chromosomal damage at diakinesis metaphase I does not 
always conform to expectations developed fron radiation or results from other chemicals such as TEM.

One of the first observations we made with ENU was how long it took for the stem cell count to reach a minimum. In our first dose-curve experiment mice were killed 3 days after injection, but the dose response was flat. for $100,150,200$, and $250 \mathrm{mg} / \mathrm{kg}$. This was unexpected, for the length of the sterfle period was known to increase with dose. Our results could be explained, however, if cell death in the long-cycling sten cell compartment was delayed. A second experiment showed this to be true, with the lowest value observed 8 days after both 50 and $100 \mathrm{mg} / \mathrm{kg}$ (Table 5). This is different frur radiation, where time at which the lowest number of cells is observed is dose-depeident (Table 3). Such a long delay in reaching a minimuri makes estimation of the number of surviving cells difficult, for recovery and continued cell loss overlap (77). That this was the case was shown by ${ }^{3} \mathrm{H}-\mathrm{TdR}$ labeling where recovery of DNA synthesis began at $48 \mathrm{hrs}$, and had reached control levels by 72 hrs after injection of $100 \mathrm{mg} / \mathrm{kg} \mathrm{ENU,} \mathrm{yet} \mathrm{cell} \mathrm{numbers} \mathrm{are} \mathrm{declinfng} \mathrm{rapidly} \mathrm{at} \mathrm{this} \mathrm{time.}$ Labeling was above control $(41-56 \%)$ from $6-9$ days, but not as high as the $75 \%$ observed 3 days after $150 \mathrm{R}$ and 5 days after $300 \mathrm{R}$.

In contrast to results with radiation, there was no difference in the number of labeled cells observed at 207 hrs in mice given ${ }^{3} \mathrm{H}-\mathrm{TdR} 24$ or $1 \mathrm{hr}$ before ENU with respective vaiues of 2.5 and $2.3 \%$ labeled spermatogonia compared to $18 \%$ for controls. This is quite different from the radiation results, where labeling of cells 207 hrs after 100-600 R given 24 hrs after $3_{\mathrm{H}-\mathrm{TdR}}$ is at the control level $(21 \%)$, but reduced to only $6 \%$ if irradiation occurs while the cells still are in $S$ (73). This result suggests that 
synchronfzation of stem cells by klling sensitive stages of the cell cycle should be less marked after ENU than after irradiation.

An effect previously not observed wth radiation or chemicals was observed for spermatocytes exposed to ENU in leptotene (77). No change was seen until 4 days later, when degeneration occurred in early pachytene. The sensitive stage was not long, but reduced the number of pachytene spermatocytes from 35 per tubule to zero in some cases. Spermatocytes in preleptotene and early pachytene were unaffected, methyln:trosourea (MNU) did not show this effect, but it was induced by $455 \mathrm{mg} / \mathrm{kg}$ hydroxyethylnftrosourea (HENI). Delayed effects of this nature have been observed previously for chemicals, for example, the delay in occurrence of chromosome breakage after 6-mercaptopurine and $\operatorname{TEM}(33,34)$ and the expression of cell lethality in spermatogonia after ENU (77). However, this phenomenon is not iimtted to chtmicals, for Irradiated spermatogonia often do not degenerate until they reach late interphase or early prophase of thei: first post-irradiation division $(62,65)$, and primary spermatocytes show no detectable damage until they reach diak1nesis-metaphase $I$, when many cells degenerate (78). For irradiation, it appears as if expresston of damage is delayed until critical stages in development are reached, but for chemicals, one cannot distinguish between delay 1n expression of inftial damage from binding to sensitive sites wh subsequent izduction of lethality.

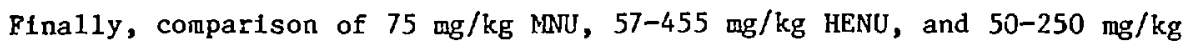
ENU revealed sinilar cytotoxic effects on the spermatogonia of the mouse (77). On the basis of the testis response, one would never predict that only EilU would be highly mutagenic in stem cells. This is another 
demonstration of the observation that all of the agents producing mutations In stem cells also are cytotoxic, but not all agents that $k 111$ stem cells are nutagens (Table 4).

The exquisite sensitivity of certain spermatogonial stages to cytatortc agents provides a sensftive test for the presence of chemicals in the testis even in the absence of genetic and fertility effects. This can have significant fopact on Interpretation of the lack of effect of a given chemical, for though not of importance in a laboratory test on a specific strain of experinental animals, both the magnitude of the response, and the sfgnificance of a small effect can vary both with species and genotype.

\section{FEMALE}

Normal oogenesis

The Initial stages of ganetorenesis, including site of origin of the primordial germ cells, thefr migration to the genital ridges, and mitotic division are the same as in the male $(2,3,12,19,55,60)$. At about 13 days in the mouse, however, the fernale germ cells begin to enter melotic prophase $(19,60)$, and by birth, all oocytes are in late pachytene, diplotene, and the arrested state of diffuse diplotene (dictyate). All oocytes enter the diffuse diplotene stage withln a few days after bitth. The same pattern of gametogenesis occurs in all species, but on different time schedules assoctated with different lengths of gestation. The rabbit is unique tn that oogonial divisions continue until about 2 weeks after birth, but in most mammals, the female is born with her total supply of oocytes. The stage of arrest is in diplotene of meiosis, but the degree of chromosome condensation vartes from the condensed nucleus of the guinea pig, the more typical diplotene of the human, to the highly diffuse 
dictyate stage of the mouse and some other rodents (74). Response of the female to cytotoxic and mutagenic agents differs greatly from the rale, for except in specific embryonic and fetal stages, the germ cells are almost exclustvely in diplotene of melosis, and oogonia do not persist after birth or the early post-natal period. Therefore, any loss of oocytes cannot be replaced, and may have irreparable effects on both pliysiology and fertility of the adult.

At the time of arrest in development, the oocyte is surrounded by a few follicle cells with small, oval nuclei and a flattened cytoplasm that completely envelops the oocyte $(6,60,80,82)$. The stimuli that initiate follicular growth are not known, but at intervals a few follicles begin to increase in size through division of the follicle cells, the oocyte begins to enlarge, formation of the zona pellucida occurs (74), the metabolic activity of the oocyte, as indicated by RNA synthesis, increases (70), and after several weeks, mature Graafian follicles are formed. Most follicles and their contatned oocytes are destined to degenerate; only a few complete development and are ovulated. Since the oocyte pool is fixed at bfrth, this normal attrition results in a continued decline in oocyte number with age $(69,83)$, and in experiments where number of oocytes are counted, it is essential that the controls are matched for both strain and age. The rate of loss is the same in pregnant and virgin ferales (69), but can be accelerated by exposure to radiation and chemicals (Fig. 25). The increased rate of loss can continue long after a single radiation exposure, and could result either from effects on the oocyte, the follicle, the relationship of the follicle cells to the oocyte, or the ovarian milieu in which the follicle develops. 
Different terminologies have been applied to the stages of follicular and oocyte growth, and as a result $t$ t often is difflcult to compare data presented in the literature. The nost precise system of classification is that proposed by Pederson and Peters (82), a slightly modified version of which is presented in Table 6 and 1 llustrated in Figures 26-36.

\section{Radiation response}

Response of the female, both in terms of genetic and fertility effects, is different from the wale owing to basic differences 1.2 gametogenesis $(2,3,55)$. The two sexes have a common response only during the early divisions of the primordial germ cells $(2,3)$; once meiotic prophase is inftiated in the ovary, the paths of gametogenesis diverge, and so likewise the response of the gonads to radiation and chemicals.

The ovary is sensitive during mitosis of the primordial germ cells, then becones more resistant as the oocytes enter melotic prophase (3). In all species so far investigated, nocytes pass through a very sensitive stage in early diplotene $(3,17,68,83)$, and in the case of the mouse, hamster, and rat, oocyte arrest occurs in this stage. In other species, the sensitive stage appears to be of short duration, and asynchrony of development protects the prenatal female from the sterilizing effect of acute radiation exposure (17). Continuous or fractionated exposure In utero can Induce permanent sterility, however, and some species are even more sensitive than the mouse when exposure occurs in utero. In the mouse, oocytes that have just reached the diffuse diplotene (dictyate) stage are more sensitive than the arrested oocyte of the adult. An $L_{50}$ of only $8.4 \mathrm{R}$ has been estimated for stage 1 oocytes of the 10-day-old mouse 
(Fig. 37). By 14-21 days, depending upon strain response of early oocytes of the mouse is comparable to that of the adult $(17,83)$.

The arrested oocyte of the adult mcise is extremely sensitive to radiation-1nduced cell death $(63,69)$, whereas comparable stages in other species are quite resistant. As the follicle and its contalned oocyre grows in the mouse, resistance to radiation increases (63) and once the growing oocytes have attained a follicle with a single layer of cuboidal cells, they have both a common nuclear morphology and a similar radiation response in all marnals so far investigated (1). In the mouse, at least one litter is obtalned after an exposure of $400 \mathrm{R}$, indicating high resistance of follicles that will be ovulated at the next estrus. On the other hand, a dose of $50 \mathrm{R}$ will induce permanert sterility after about 4 litters owing to destruction of arrested oocytes in the smallest follicles. Response of mature oocytes is simflar in the human female, where one or two menstrual cycles occur after acute radiation exposures of $300-400 \mathrm{R}$ $(49,100)$. A period of amenorchea then sets $i n$, but in contrast to the mouse, ovulations begin again several months to a year later owing to development of the radiation-resistant "arrested" oocytes $(49,100)$. Because of these differences, the female mouse of ten is considered a poor model for the human ( 1 ). This is true as far as fertility is concerned, but as will be shown in the following paragraphs, has little relationship to genetic effects.

After an exposure of $50 \mathrm{R}$ of $\mathrm{x}$-rays, all the mutations obtained in the mouse are from conceptions occurring in the first 7 weeks after exposure (91); the observed mutation rate in litters conceived more than 7 weeks after irradiation is actually (but not significantly) below the control 
rate. In evaluating the relevance of genetic data in the mouse to other species, it therefore becomes important to identify the stage in oocyte development at which this shift in mutational response occurs. Timing of oocyte growth by labeling the zona pellucida with $\mathrm{N}-\left[{ }^{3} \mathrm{H}\right]$ acetyl-Dglucosamine, $\mathrm{D}-\left[1-^{3} \mathrm{H}\right]$ glucosamine, and $\mathrm{N}-\left[1-^{3} \mathrm{H}\right]$ fucose indicated that the change occurs after the oocytes have initiated growth, and in a stage that is similar both in nuclear morphology and in radiation response in all mammals (74). The early oocyte that is sensitive to killing in the mouse therefore has no bearing on spectes comparisons for genetic effects, and the mouse may be a better model for mamals than 1 s commonly thought. It appears logical that 2 cell with as long a 11 fe span as the oocyte (months in mice, decades tn the human) would evolve efficient repair ruechantsms, and the only comparison that has been made suggests that this indeed may be true, fo julnea pigs have arrested oocytes that are resistant to radiation-induced k.tllirg, yet they also show a low frequency of dominant lethals just as do early oocytes in mouse and hamster (16).

Early oocytes of the mouse make a sensitive test system for measuring the cytotoxicity of radiation and chemicals (Fig. 37) and for deronstrating the presence of such agents even in the absence of genetic and fertility effects. Quantitation of follicle stages $1-3 b$ is straightforward, for degeneration in controls is rare among these stages. In zreated mice, degeneration is rapid and oocytes can be counted $72 \mathrm{hr}$ after treatment without difficulty. As the follicle acquires rultiple layers of cells, however, the frequency of degenerating follicles in control mice 1ncreases, and in some stages, especially 5 and 6 , the majority of follicles are atretic. It has long been known that degeneration is the common fate of 
most follfcles and their contained oncytes, with only a few reaching ovulation. This causes no problem in the normal course of reproduction, and there is some evidence that degenerating follicles serve a hormone secreting role. However, this high level of atresia does cause serious problems in evaluating the effect of noxious agents on the ovary, especially since no exact criteria exist for classifying follicles as normal or atretic. A complete continaum from the unquestionably normal to the obviously degenerate with corresponding variations in frequencies of necrotic cells and apparently normal mitoses occur in all follicle stages of more than two layers. Quantitation of the growing follicles therefore is highly subjective.

The effect of oocyte loss is expressed at the end of the reproductive span $(29,69)$. An experiment where $25 \mathrm{R}$ of $\mathrm{X}$-rays was given to 10 -day-old females is used as an example (Fig. 38). Oocyte numbers were reduced to only $3.9 \%$ of control at 56 days, when the females were nated, yet reproductive performance was reduced to on 1 y $35 \%$ of control (69). Reproduction in the irradiated group ceased by 38 weeks, whereas matched controls continued to breed for 75 weeks (Fig. 38). Docyte counts given in Fig. 25 reveul two interesting phenomena: (1) oocyte loss occurs at a more rapid rate in the irradiated than in the control females, and (2) sterility occurs in the irradiated females because the oocyte supply is exhausted whereas it occurs from physiological reasons in controls, for several hundred oocytes remain in the ovaries of control females at the end of their reproductive cycle. Such effects may be difficult to detect in other species, such as the human female where number of births is low, and usually limfted to the early part of the reproductive span. Physiologtcal 
consequences of an earlier than normal onset of menopause because of depletion of the oocyte pool, however, deserves serious consideration. Chemicals. Investigation of the effects of chemicals on the ovary is much more limited than for the testis, but the data are adequate to demonstrate effects that are a hazard to reproductive performance. In addition to direct effects on the ovary, the response of females is complicated by possible physiological effects on ovulation, implantation, and maintenance of the embryo and fetus.

Embryo and fetus. Only a few studies have been made on the embryo and fetus, but they are adequate to demonstrate that dividing primordial germ cells and oogonia are more sensitive to the cytotoxic action of chenicals than the oocytes of either the late fetus or adult (59). For example, iscpropyl methane sulfonate (IMS) induces sterility in the fenale offspring if given to the pregnant rat on day 13 or 14 , is less effective on days 15 and 16, and has no effect on fertility if given on day 20 . Azathioprine and 1 ts active metabolfte, 6-mercaptopurine, also are toxic to oocytes of the developing ovary, but not in the adult ovary $(56,59)$. Those compounds showing oocyte toxiclty in the adult (cyclophosphamide, benzo[a]pyrene, IMS), have proven to be cytotoxins in the developing ovary as well (59). Owing to higher sensitivity to both radiation and chemicals, exposure of the fetal and neonatal ovary can have serfous effects on subsequent reproductive performance. Yet, this is a neglected area of research. Furtherwore, a compound like 6-mercaptopurine which has no effect on fertllity of the adult mouse, but can sterilize both nales and females In utero (59) demonstrates that risk of chemical exposure cannot be fully evaluated by tests on the adult. 
Adult. Conpared to the male, relatively few studies have been made on the effect of chemicals on fenale reproduction, but they reveal the sane complexity of response observed In the rale, with the added variable of genotype $(25,29,32,35,58)$. Female mee of different strains not only vary in their sensitivity to the direct action of cytotoxic agents, but also in their abilily to repalr genetic danage Induced in the male after the sperm has entered the egg. Also, analysis of fertility effects in females can be affected by possible physiological effects on ovulation, implantation, and mafintenance of the embryo.

With the exception of IMS, which kilis follicles with an antrun (32), chemicals that affect ferale fertility do not interrupt continued development and ovulation of oocytes that have initiated growth, but once ovulated, they are not replaced owing to destruction of the "arrested" oocytes in small follicles. This response is similar to that observed for radiation exposure, and myleran, 9, 10 - Dimethyl - 1,2 -Benzanthracene, Trlethylenemelamine (TEM), cyclophosphamide, benzo[a]pyrene, and ethylnitrosourea are examples of this class of chemicals (Table 7). Reduction in fertility is expressed at the end of the breeding span, and it is important that total reproductive performance be assessed in order to detect an effect $(29,69)$. This is especially true for compounds such as 6-mercaptopurine, methylmethanesulfonate (MMS), chloro-9-[3-(ethyl-2chloroethyl)amino propylaminol acridine dihydrochloride (ICR-170), ethy1 methanesulfonate (EMS), and $\mathrm{N}$-methy1-N'-nitro-N-nitrosoguanidine (MNNG) that have only a slight effect (29).

In cases where netther fertility nor genetic effects are observed, reduction in number of oocytes often can be detected by counts of serial 
ovarian sections. The procedure is the same as described for $\mathrm{x}$-rays, and has been used extensively by Mattison $(56,57,58,59)$ and others in an analysis of the effect of polycyclic aromatic hydrocarbons on the ovary. As pointed out for $X$-rays, these effects may not affect reproduction in laboratory animals, but they may have serlous physlological consequences in other species, for example, an earlier onset of the menopause in women. Also, we have to recognize that there not only are species differences in response to chemicals but that genotype also is a significant variable $(35,58)$.

MECHANISM OF CELL DEATH

In spite of decades of work, the mechanisms involved in cell death remain obscure. It is known that chromosone breakage leading to aneuploidy or heteroploldy of daughter cells can lead to cell death, but this cannot be a major factor in spermatogonial or oocyte kil1ing, for most speratogonia degenerate in late interphase or prophase before they divide $(62,65)$, and the oocytes most sensitive to cell-kililing are arrested in diplotene of meiotic prophase. The response can be lomedlate with detectable changes in the cells as early as $3 \mathrm{hr}$ after trradiation, or it can be delayed, as demonstrated by the response of stem cells and spermatocytes to both radiation and chericals. For example, a single exposure of $25 \mathrm{R} \mathrm{Co}{ }^{60} \gamma$ rays results in accelerated oocyte loss up to 200 days later (FIg. 25). Furthermore, one must account for the changes in response with differentlation and development, the differences in response between even closely related spermatogonial classes, the unique response of different melotic prophase stages, and the changing response during spermiogenesis. Also, what occurs during growth of the mouse oocyte to 
change it from a cell refractive to mutation induction and sensitive to cell killing to a cell sensitive to mutation induction and resistant to cell killing by radiation? It is easy to associate response to a noxious agent with morphologically recognizable cell stages, but this may be possible only because of correlated and unknown biochemical and physlological differences involved in the intricate biological process of differentiation.

The organization of the chromosomes of the arrested oocyte has received considerable attention in reference to cell killing $(1,70,74)$ but this hypothesis is difficult to reconclle with the fact that the oocyte is in diplotene of melotic prophase, with a $4 \mathrm{~N}$ complement of DNA. It is difficult to see how doses of only a few rads could induce sufficient chronosome damage to kill the cell, with degenerative changes evident even minutes after frradiation. The high sensitivity of the mouse oocyte suggests that the sensitive target either is the entire cell, or that there are a large number of small targets, Inactivation of any one of which will lead to cell death. The work of Parsons (80) with radiation, and of Gulyas and Mattison with chenicals (39) indicate that the mitochondria are the first cellular organelles to be affected. This would also agree with the destruction of growing oocytes with ${ }^{3} \mathrm{H}$-uridine $(70)$, for the beta radiation would be concentrated in the PHA-rich cytoplasmic organelles.

In the male, the existence of $A_{p r}, A_{a l}$, and all differentiating spermatogonta in a syncytial arrangenent provides an amplification mechanlsm, for these cells efther survive or degenerate in groups (45). The observed progression of degenerative changes in groups of cells with cytoplasmic connections strongly suggests that inactivation of one cell 1 s 
sufficient to kill the entire group. Thus the effectlve target size is much larger than the single cell, and as a result, the effect of doses as low as 3 rads of $\gamma$ rays can be detected on the $A_{4}$ and In spermatogonia of the mouse.

Even though we do not yet understand the mechanism of cell. killing, the exquis!te sensitivity of the primordial germ cells, oogonia, gonocytes of the embryo and fetus, and the differentiating spermatogonia and arrested oocytes of the mouse to cytotoxins make these excellent test systens for detecting the presence of noxlous agents. The relationship of this cytotoxicity to fertility is direct. Killing of germ cells in the embryo and fetus affects Iffetime reproductive performance in both males and females. Even though temporary sterlitty may be induced in the adult male, fertility eventually returns if a sufficient number of stem cells survive. In the female, however, oocytes cannot be replaced, and reduction in oocyte nunbers can result in prenature onset of sterility.

The relationships of cell killing to genetic effects is more complex and less direct, and acts priuarlly by altertng the frequency distribution of stem cells among stages of the mitotic cycle, and by affecting the cell stages avallable for testing, and thereby, the types and frequencies of genetic effects observed in the offspring.

\section{ACKNOWLEDGEMENTS}

The author is grateful to Miss C. D. Crosthwalt for her help in compling the Ifterature on chemical effects, and to $W$. M. Generoso and G. A. Sega for reviewing the manuscript. 


\section{REFERENCES}

1. Baker, T. G. (1973) The effects of tonizing radiation on the mammalian ovary with partirular reference to aogenesis, In: Handbook of Physiology, Section 7: Endocrinology, Volume II, Female Reproductive Syster, Part 1, R. O. Greep, B. A. Astwood, S. R. Gelger, Eds., American Physiological Society, Washington, D.C. pp. 349-361.

2. Beaumont, H. M. (1960) Changes in the radiosensitivity of the testis during foetal development. Int. J. Rad. Biol. 2:247-256.

3. Beaumont, H. M. (1961) Radiosensitivity of oogonia and oocytes in the foetal rat. Int. J. Rad. Biol. 3:59-72.

4. Benda, C. (1887) Untersuchungen uber den Bau des funktionerierenden Samenkanälchens elniger Sängetiere und Folgerungen flir die Spermatogenese dieser Wirbeltierklasse. Arch. Anat. Microsc. Morphol. Exp. 30:49-110.

5. Bhattacharjee, D., T. K. Shetty and K. Sundaram (1978) Cytotoxicity of ethyl methanesulfonate in mice spernatogonia. Experientia 35(5): $630-631$.

6. Brambell, F. W. R. (1927) The development and morphology of the gonads of the mouse. I. The morphogenesis of the indifferent gonad and of the ovary. Proc. Roy. Soc. (Lond.) B 101:391-408.

7. Brenneke, H. (1937) Strahlenschädigung von Măuse - und Rattensperma, beobachtet a: der Frihent wicklung der Eler. Strahlentherapie $60: 214-238$. 
8. Brewen, J. G., H. S. Payne, K. P. Jones and R. I. Preston (1975)

Studies on chenically induced dominant lethality. I. The cytogenetic basis of MMS and induced dominant lethality in post-meiotic male germ cel1s. Mut. Res. 33:239-250.

9. Bullough, W. S. (1948) Mitotic activity in the adult male mouse, Mus. musculus L. The diurnal cycles and thelr relation to waking and sleeping. Proc. Roy. Soc. B 135:212-233.

10. Cattanach, B. M., C. E. Pollard, J. H. Isaacon (1968) Ethyl methanesulfonate-induced chrowosome weakage in the mouse. Mut. Res. $6: 297-307$

11. Chang, M. C. D. M. Hunt, and F. B. Romanoff (1957) Effects of radio-cobalt irradiation of rabbit spernatozoa in vitro on fertilization and early development. Anat. Rec. 129:211-229.

12. Chiquoine, A. D. (1954) The identification, origin, and migration of the primordiai germ cells in the mouse enbryo. Anat. Rec. 118: $135-146$.

13. Clermont, Y. (1968) Différenciation et evolution des cellules sexuelles 1. La lignée male. Cinetique de la spermatogenèse chez les Maımiféres, In: La Physiologie de la Reproduction les Mammiféres, A. Jost, Ed., Editions du centre National de la Recherche Sclentifique, Paris, pp. 7-60.

14. Clermont, Y. and E. Bustos-Obregon (1968) Re-examination of spermatogonial renewal in the rat by means of seminiferous tubules mounted "in tot". Am. J. Anat. 122:237-248. 


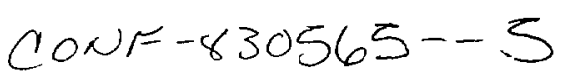

Submited to:

$D E Q 3 \quad 012556$

Basic Life Sciences (Plenum

Press). Proceedings of the

"International Workshop on the Principles of Environmental

Mutagenesis, Carcinogenesis and

Teratogenesis" held May 25-June 1,

MASTER 1983 in Shanghat, The People's Republic of China.

DOMINANT-LETHAL MUTATIONS AND HERITABLE TRANSLOCATIONS IN MICE`

Walderico M. Generoso

Biology Division, Oak Ridge National Laboratory, Oak Ridge, TN 37830

\title{
DISCLAIMER
}

\begin{abstract}
This report was prepared as an account of work sponsored by an agency of the United States Government. Neither the United States Government nor any agency thereof, nor any of their employees, makes any warranty, express or implied, or assumes any legal liability or responsibility for the accuracy, completeness, or usefulness of any information, apparatus, product, or process disclosed, or represents that its use would not infringe privately owned rights. Reference herein to any specific commercial product, process, or service by trade name, trademark, manufacturer, or otherwise dnes not necessarily constitute or imply its endorsement, recommendation, or favoring by the United States Government or any agency thereof. The views and opinions of authors expressed herein do not necessarily state or reflect those of the United States Government or any agency thereof.
\end{abstract}

By acceptance of this article, the publisher or recipient acknowledges the U.S. Government's right to retain a nonexclusive, royalty-free license in and to any copyright covering the article.

Research sponsored by the Offlce of Health and Environmental Research, U.S. Department of Energy under contract W-7405-eng-26 with the UnIon Carbide Corporation.

Abbreviations: BaP, benzo[a]pyrene; IMS, 1sopropyl methanesulfonate; EMS, ethyl methanesulfonate; MMS, methyl methanesulfonate; ENU, ethylnitrosourea; MNU, methylnftrosourea; TEM, cricthylenemeiaminine; Eto, ethylene oxide. 
TABLE OF CONTENTS

PAGE

SUMMARY . . . . . . . . . . . . . . . . . . . . . 2

INTRODUCTION ........................... 3

DOMINANT-LETHAL MUTATIONS . . . . . . . . . . . . . . . . . 3

Historlcal background ...................... 3

Expression of dominant-lethal effects . . . . . . . . . 4

Spermatogenesis stage differences in sensitivity tc

dominant-lethal induction .............. 5

Differences between stocks of females in their yield of

dominant-lethal mutations ............... 7

Differences between stocks of males in their sensitivity

to induction of dominant-lethal mutations . . . . . . . 7

General procedure for dominant-lethal test in males . . . . . 8

Treatment of parental males . . . . . . . . . . . . 9

Making procedure .................... . 9

Selection of females for use in the dominant-lethal test . . . . 10

Evaluation of mutagenicity ... . . . . . . . . . . . . 11

HERITABLE TRANSLCCATIONS . . . . . . . . . . . . . . . . . 11

Historical background . . . . . . . . . . . . . . 12

Effects of translocations among carrlers . . . . . . . . . 13

Inductbility of heritable translocations at various stages

In male gametogenesis ........ . . . . . . . . 14

General procedure for the heritable translocation test . . . . . 15

Treatment of parental males . . . . . . . . . . . . 15

Mating procedure .. . . . . . . . . . . . . . . 16 
Testing of male progeny for translocation heterozygosity . . . . 16 POSSIBLE MECHANISM FOR CHEMICAL INDUCTION OF DOMINANT-LETHAL

MUTATIONS AND HERITABLE TRANSLOCATIONS . . . . . . . . . . . 17 REFERENCES . . . . . . . . . . . . . . . . . . . . . . . 21 


\section{SUMMARY}

Chromosome abeirations are a major component of radiation or chenically induced genetic damage in mamnalian germ cells. The types of aberration produced are dependent upon the mutagen used and the germ-cell stage treated. For example, in male meiotic and postmelotic germ cells certaln alkylating chericals induce both dominant-1ethal mutations and heritable translocations while others Induce primarily dominant-1ethal mutations. Production of these two endpoints appears to be determined by the stability of alkylation products with the chromosomes. If the reaction products are intact in the male chromosomes at the time of sperm entry, they may be repalred fn fertilized eggs. If repair is not effected and the alkylation products persist to the time of pronuclear chromosome replication, they lead to chromatid-type aberrations and eventually to dominant-lethality. The production of heritable translocations, on the otiner hand, requires a transformation of unstable alkylation products Into suitable intermediate lesions. The process by which these lesions are converted into chromosome exchange within the male genome takes place after sperm enters the egg but prior to the time of pronuclear chromosome replication (i.e., chromosome-type). Thus, dominant-lethal mutations result from both chromatid- and chromosone-type aberrations while heritable translocations result primarily from the latter type. DNA target sites associated with the production of these two endpoints are discussed. 


\section{INTRODUCTION}

Chromosome breakage contribute heavily to human genetic burden. It may result in chromosome loss, which of ten leads to lethality but occasionally to viable aneuplotds, or to viable exchanges and inversions. In mice this class of genetic damage is readily induced in certain germ cells by ionizing radiations and by numerous chemical mutagens. Thus, transmissible shromosomal aberrations resulting from induced breaks and rearrangements are certainly a major concera In the evaluation of genetic risk. How they are produced in germ cells and what their consequences are in affected conceptuses are important question in our attempt to evaluate genetic risk from exposure to chemical mutagens and in understanding the mechanisms for aberration incuction.

Aberrations that lead to early lethality among conceptuses do not contribute to the population's genetic burden for obvious reason. On the other hand, aberrations that permit survival and reproduction have untoward effects on the affected individuals as well as on some of their immediate descendants. In mice, dominant-lethal mutations and heritable translocations not only best exemplify these two classes of end effects but they are also the most widely used endpoints of transmitted chromosome breakage effects In practical testing and hazard evaluation. Thus, this report will be restricted to the discussion of these two endpoints as they are used in practical testing - i.e., response of male germ cells - with emphasis on possible mechanisms for induction.

II. DOMINANT-LETHAL MUTATIONS

A. Historical background

Dotinant-lethal mutations are genetic changes in parental germ cells that cause death of affected first generation progeny. The earliest information on 
doninant-lethal effects in mamals came from experiments with ionizing radiation (see the extensive reviaw by $W$. L. Russe11, 1954). It was first observed that exposure of male laboratory animals to $X$ rays prior to nating during the presterile period resulted in the increase in abnormal embryos and reduction in litter size. These effects were shown eventually to be caused by induced chromosomal aberrations.

The first observation of dominant-lethal effects induced by a chenical mutagen was made with the compound TEM. Jackson and Bock (1955) observed that males given either a slugle dose, or daily doses for five consecutive days, or daily doses of TEM for a prolonged perlod became infertile even though the males mated normally and produced spermatozoa during and after treatment. This "infert1lity effect," which was also observed in nice, was found shortly to be the result of early embryonic death (Cattanach and Edwards, 1958; Steiaberger et al., 1959; Bateman, 1960). The demonstration by Cattanach (1957) that TEM induced heritable translocations at the male postmeiotic stages in which embryontc lethality effects were also assoclated suggested strongly that chromosomal aberrations were the cause of the doninant-lethal response. This cause and effect relationship was later proved from cytological analysis of first and early cleavage embryos (Matter and Jaeger, 1975; HitotsumachI and Kikuchi, 1977; Bark1 and Sheridan, 1978). Actually, an "infert1lity effect" simflar to that Induced by TEM was reported first for nitrogen mustard by Falconer, Slizynski and Auerbach (1952). However, up to this time dominantlethal data for this compound are inconclusive.

\section{B. Expression of dominant-lethal effects}

In mice, embryonic death resulting from dominant-lethar mutations are usually expressed betwen the two-cell stage and short $1 y^{\text {y }}$ after tuplantation. 
Low levels of dominant-lethal effects are usually expressed in terms of Increased number of deciduonata. Doninant-lethal mutations that are expressed in embryos that fall to Implant are usually observed when dominant-lethal effects are high. In fact, at extreme levels, all embryos in a female may die wel1 before implantation that the female shows no slgn of pregnancy. An example of induced dominant-lethal effects is shown in Table 1 whero induced effects were observed in the following order as a function of dose: increase in percent dead implants, reduction in the average number of living embryos, reduction in the average number of total implants, and reduction in the proportion of pregnant females among mated ones. It is generally belleved that inducec dominant-lethal mutacions are almost exclusively chromosome breakage events. The dominant-lethal test is useful for testing the mutagenicity of chemicals. It is a simple and quick procedure. Many laboratorjes throughout tile world are now using this method in practical testing.

C. Spermatogenesis stage differences in sensitivity to dominant-lethal induction

It is extremely important for anyore who Intend to use the dominant-lethal test to have a good understanding of the variety of responses by various stages in spermatogenesis to chemical mutagens. To date, a great number of chemicals had already been studied for induction of dominant-lethal mutations in male mice. Those that are clear-cut inducers induced dominant lethals only at specific stages in spermatogenesis - i.e., none of them induced dominant lethals at all stages in spermatogenesis and the stage or stages affected may vary from one chemical to another. To illustrate stages differenses, only a few chemicals will be considered here. 
Chemicals differ dramatically in the stages at which dominant lethals can be induced. For instance, isopropyl methanesulfonate (Eh1ing et a1., 1972) and triethylene melamine (Cattanach and Edwards, 1958) induce doninant lethals in spermatozoa, spermatids and spermatocytes; ethyl methanesulfonate, methyl methanesulfonate and n-propyl methanesulfonate only in spermatozoa and spermatids (Ehling et al., 1968; 1972); Myleran in spermatozoa and spermatocytes (Ehling and Malling, 1968); Mitonycin C, in spermatids, spermatocytes and possibly differentiating spermatogonia (Ehling, 1971) and 6-mercaptopurine exclusively ln late differentiating spermatogonia and possibly early meiotic spermatocyte (Ray and Hyneck, 1973; Generoso et al., 1977). It should be noted that all chemicals mentioned here induced dominant lethals in postmeiotic germ cells in one stage of development or another with exception of 6-merc.stopurine. So far, no ciemical agent has been shown unequivocably to be effective in inducing dominant lethals in spermatogonia ster cells. This is not to say that no chemical induce chromosome breakage in spermatogonia sten cells. On the contrary, there is evidence although equivocal, through cytological analysis of spermatogonial metaphases (mixture of differentiating gonia and stem cells), that certain chemicais do break chromosomes of these cells (Adler, 1974; Luippold et al., 1977). If, indeed, chromosome breakage is induced at this germ cell stage, the absence of dominant-lethal effect may be explained by the possibility that cells with chromosone lesion do not make it to the ejaculate i.e., they are lost sometime during spermatogonial divisions and spermatogenic maturation. 


\section{Differences between stocks of females in their yield of dominant-} lethal mutations

The oocyte is ovulated with its chromosomes in the metaphase of tha second meiotic division. It remains in this state until stimulated by sperm entry to undergo further development. The fertilized egg of mice can repair certain premutational lesions present in the fertilizing sperm and the yield of dominant-lethal mutations $I_{s}$ affected by the strain of females used to mate with the treated males (Ceneroso et al., 1979a). The ability of fertilized eggs to carry out repair and permit survival of the embryo varies from one strain to another depending on the chenical mutagen used. However, we have found that certain strains of fenales consistently gave relatively high dominant-lethal frequencies for all chemical mutagens we have studied so far. Because the genotype of the egg has significant role in the processing of premutational lesions that are carried in the chromasomes of mutagen-treated male germ cells, this phenomenon must be taken into consideration in practical testing. Without addressing this problem, negative results may simply mean that treated males were mated to females from repair--competent strains.

E. Differences between stocks of males in their sensitivity to induction of dominant-lethal mutations

The yield of dominant-lethal mutations may or may not be affected by the stock of males treated depending upon the mutagen used. As shown in Table 2 the yield of EMS-induced dominant lethals for $(101 \quad \mathrm{C} 3 \mathrm{H}) \mathrm{F}_{1}$ was about twice as much as that for T-stock males. A similarly clear-sut difference between these two stocks exist for IMS with T-stock males showing the lower dominant-lethal effects than $(101 \times \mathrm{C} 3 \mathrm{H}) \mathrm{F}_{1}$. T-stock males, however, are not always relatively more resistant to mutagentc chemicals. It can be seen in Table 2 that r-stock 
dally doses. Therefore, depending upon the nature of the test chenical, it may be necessary to use more than one treatment procedure.

\section{Treatment of Parental Males}

Generally, three methods of treatment are used in practical dominant-lethal testing-single dose, dally dosing for five consecutive days and dafly dosing for 8 weeks. Whatever method of treatment is used it is generally believed that the test should include the maximum non-toxic dose or concentration (also called maximum tolerated dose, MTD, or concentration, MTC). The MTD information, If not yet available, should be determined first in a toxlctty study, In which, Imnediately after treatment (in case of single dose) or Immediately after the last dosing (in case of repeated treatment) or ai the last day of exposure (in case of feeding studies) surviving males are to be caged with untreated females in order to find out the effect of treatment on the mating ability of males.

The optimum number of parental males to use in a dominant-lethal experiment depends in part on the ability of the males to breed and on the reproductive performance of the females. When suitable males and females are used, 36 males for each experimental and control groups should be adequate.

\section{Mating procedure}

The mating protccol to use depends unon the treatment procedure used. Males given a single dose and males given five consecutive daily doses should be mated serially for at least 8 weeks. This length of mating pericd will ensure analysis of the response of the varlous stages in spermatogenesis. Males that are exposed for 8 consecutive weeks, on the other hand, would have had their germ cells exposed to the chemical throughout the time spermatogenic cells are 
going through the maturation process. Consequently, these males need to be mated an 1; for one week beginning inmediately after the end of exposure.

When libidr. 's not a problem, each treated aale is cagisd with two untreated females. Every lu.ning, females are examined for presence of vaginal plugs (indication of mating) and each female that copulated is removed and replaced by a virgin female. All mated females are killed for uterine analysis 12 to 15 days after observation of the vaginal plug.

\section{G. Selection of females for use in the dominant-lethal test}

In addition to the repalr phenomenon described in Section II,D, there is another important consideration tn choosing the strain of females to use in the dominant-lethal test. This has to do with the varlous criteria (see Section II-1) for evaluating dominant-lethal effects. All criteria are based upon information obtainable from analysis of the uterus sometime after females had been mated. Of particule:= importance is the notmal incidence of dead implantation because clear-cut increases in the incidence of dead implants is an unequjucal evtdence that dominant-1ethal mutations were induced in treated males. Obviousiy, it is most desirable to use a strain of ferales in which the normal inctdence of dead implantation is low. It should be emphasized that the incldence of dead implantation can vary greatly, not only with age, but also with strain of females. Examples of normal inctdence of dead implantation in control females from vartous strains is shown in Table 3 . In addition to low frequency of dead implantation, other qualities of desirable strains are large litter size, high proportion of matings (as indicated by vaginal plugs) during the receptive stage of the estrous cycle and high uniformity among females. These characteristics are more likely to be found among hybrid and random-bred stocks than in 1nbreds. 


\section{H. Evaluation of Mutagenicity}

Mutagenicity of the test compound is decided by a combination of the following criteria: (1) increase in the frequency of dead implantations, (2) increase in the number of females with one or tore dead implants, (3) reduction in the average number of living embryos, (4) reduction in the average number of implantations and (5) reduction in the frequency of fertile matings. Generally the first three criteria and, in some cases (when the fiuduction rate is high), also the fourth criterla are expressed together. The fifth criterion is expresse 3 only whe, dominant-lethal induction approaches 100\% i.e. each fertilizing sperm carries at least one lethal mutation that results in embryonic death prior to implantation. Apparent sterility of some treated males may be tue to dominant lethality or to physiologic reasons such as the inability of treated inales co mate duriag the postreatment sick phase; thus the value of checkin o vaginal plugs. In experinents where maies are serially mated, analysis nay be done on data pooled into successive two-day interyals. In experiments where males are mated for only one week, data may be pooled intr. Fo Eroups - first four days and last three days.

\section{HERITABLE TRANSLOCATIONS}

One of the consequences of chromosome breakage induced in specific stages in male gametggenesis is the production of symmetrlcal reciprocal translocations which can be passed to sone of the first generation progeny. Carriers of these translocations, referred to as translocation heterozygotes, are highly viable and ge aerally cannot be distinguished froln normal mice by casual observation of progeny. Because heritable translocations are by definition, scored among 11ve 
progeny, they provisie a very definitive and unequivacal measure of chromosonebreakage effects. Furthermore, they are generally considered to be the nost important endpolnt of induced chromosome aberrations with respect to genetic risk assessment.

A. Historical background (see reviews by W. L. Russell, 1954 and W. M. Generoso et a1., 1980)

Like dominant-lethal mutations, the initial evidence that heritable translocations in mice are readily inducible in certain postspermatugonial stages came from early studies with ionizing radiation which showed that among progeny of Irradiated males there we a number of semisterile aulmals which transinited the semisterile characteristic to about half of their progeny (Snell and co-workers 1933, 1934, 1935). The hypothesis that the cause of semisterility was the presence of a translocation which led to the production of gametes with unbalanced chromosone constitution was confirmed a few years later through genetic (Snel1, 1941, 1946) and cytological (Koller, 1944; Koller and Auerbact., 194i) studies.

In the late 1940 s and early 1950 s when it was already clear that, like $\mathrm{X}$-rays, nitrogen mustard compounds have the ability to induce chromosome rearrangements in several spectes, attempts were made to see if this effect could be found in the mouse (Auerbach and Falconer, 1949; Falconer et al., 1952). Although one of these studies (Falconer et al., 1952) indicated the effectiveness of titrogen mustard, it falled to demonstrate convincingly the induction of heritable translocation when male mice were treated with this chemical. This fallure nay be attributed to the low number of progeny tested. Uníortunately, no further siudy with nitrogen rustard has been reported. 
In 1957, the first siudy showing clear-cut evidence of the induction of heritable translocations by a ciemical, triethylenemelamine (TEM), was reported (Cattanach, 1957). Subsequent studies with TEM and other alkylating chemicals showed that heritable translocations are readily induced in male postmelotic and melotic stages but not in earlier stages.

\section{B. Effects of translocations among carriers}

Approximately one-third of all chemically or radiation-induced

transiocations result in male sterflity. The nature of these translocations has been studied extensively (Cachetro et al., 1974; Cache1ro, 1977, Russell and Montgomery, 1969). One general class of translocations that results in male sterility consists of sex-chromosome - autosome translocations. Anotiner general clacs, wht: $n$ constitutes the majority of induced cases of $\mathrm{F}_{1}$ male sterility, involves trat ilocatlons between autosomes in which at lesst one of the breaks occurs close to one end of a chromosome (either distal or proximal). Dccasionally sterility also ensues when nore than one reciprocal translocations are preseni. The great majority of sterile males have distinctly small testes (about one-third that of normal size). In most cases, spermatogenesis is blocked at one stage or another; of the few that have sperm in the epididymis, the concentration is markedly lower than normal and the sperm are generally nonmotile with a high frequency of morphological abnormalities, such as bent tail. Generally, females that are heterozygous for either class of translocation are semistertle (Generoso et al., 1978a; Russell and Montgonery, 1969).

The rest of the translocations are of the partlally sterile kind. The degree of partial sterilfty is dependent upon the proportion in whlch balanced and unbalanced gametes are represented in the ejaculate, and this in turn is a 
function of meiotic segregation. The unbalanced sperm, which are produced through adjacent-1 and adjacent-2 segregations and 3-1 misdivision, are capable of fertilization, but they lead to early enbryonic lethality observed primarily as resorption moles. The degree of partial sterility may vary from that which is substantially lower to that which is substantically higher than $50 \%$. On the average, the percentage of living embryos among normal fenales that were mated to partially sterile translocation males is only $43-44 \%$ that of normal females that were mated to normal males (Table 4). This indicates that the percentage of gametes with unbalanced chromosome constitution in the ejaculate is $56-57 \%$. There is evidence that the length of translocated chromosome segment has some influence on the proportion of unbalanced gametes in the ejaculate (Gineroso et a1., 1981). Long translocated segments appear to favor the formation of unbalauce. ;ametes.

In addition to fertility effects certain translocations may have other adverse effects. For example, Sf lby (1979) have found three different translocations, each of which was associated with specific skeletal abnormality. We have recently found a translocation that is associated with behavioral abnormality (chromosomal and pathological studies $x$ this translocation stock is in progress).

C. Inducibility of heritable translocations at various stages in male gametogenesis

I.Ike dominant-lethal mutations, Induction of heritable translocations is stage dependent (Generoso et a1., 1978). Arong chemicals studied so far, only alkylating chemicals have been shown to clearly induce heritable translocations. However, not all alkylating chemicals are effective in inducing heritable translocations. Chemically induced heritable translocations have been recovered 
only from treated meiotic and postmelotic germ cells of males. Extensive study on spermatogonia stem cells showed that none of the chemicals studied (TEM, TEPA and cyclophosphanide) significantly induced heritable translocations at this germ ce11 stage. Ionizing radiation, on the other hand, are clearly effective in inducting heritable translocations in the gonia stem cell (Generoso et al., in press). This striking difference between alkylating chentcals and ionizing radiations is surprising in view of the fact that the chemicais studied, like Ionizing radiations, are potent inducers of herttable translocations in male postmelotic stages. To date, there is no satisfactory explanation for this difference.

\section{General procedure for the heritable translacation test}

The heritable translocation test is carrled out in the following sequence: (1) treatment of parental males, (2) mating of treated males and production of first generation progeny (3) testing of progeny for translocation heterozygosity and (4) statistical analysis of data. Detailed presentations of the basic principles and extent of use of the heritable translocation test were published previously (Generoso et al., 1978; 1980). Please refer to these publications for details.

\section{Treatment of parental males}

Because of stage specificity, the treatment and mating procedures must ensure the sampling of the most sensitive stage to the test chemical if this chenical is indeed a mutagen. Unlike in the dominant-lethal test, it is not practical to use the single dose or the five consecutive days regimen followed by a long-term mating schedule because in order to ensure adequate sampling of the most sensitive peri,d would require large total numbers of progeny. Thus, 
the only practical method of treatment for the heritable translocation test is to subject parental males to long-tern exposure. It was mentioned earlier that heritable translocations were induclble by chemical rutagens only in melotic and postreiotic stages. To ensure treatment of these stages, males need to be exposed continuously for a rinimum of 5 weeks. Exposure time may be extended to 8 weeks or longer to allow manifestation of effect the chemical may induce on gern-cell maturation (e.g. enzymatic alteratiois) in ways that could increase subsequent sensitivity to chenically induced chromosomal lesions. If only one dose level is used, this dose should be the ITD. Finally, because the primary use of the heritable translocation data is in genetic risk assessnent, the route of administration should be the one that is rost relevant to human situation.

\section{Mating Procedure}

When libido is not a problem, each treated male is caged with two untreated females for a period of one week immediately after the end of treatment. As a general rule, larger effects are expected when males are mated cicser to the end of treatment. At the end of one week, females are separated fron males and caged individually. All male progeny are weaned and all female progeny are discarded.

\section{Testing of Male progeny for translocation heterozygosity}

Screening for translocation heterozygotes may be accomplished by using one of two general procedures. The first method, referced to as fertility technique, consists of testing the males inftially for sterility and partial sterility (also referred to as semisterility) and subsequently cytological analysis of suspect progeny. The other method bypasses the fertility cest; all male progeny are subjected to cytological analysis (cytological technique). 
These procedures were describec in detail in Generoso et al., 1978 and 1980 publications.

IV. POSSIBLE MECHANISMS FOR CHEMICAL INI'TCTION OF DGMINANT-LETHAL MUTATIONS

AND HERITABLE TRANSLOCATIONS

Ger cell stages differ from one another in many biological properties, Including repair competency and interval between $S$ phases, and it is reasonable to assume that any particular mutagenesis-related mechanism that operates for one germ cell stage may not necessarily operate for another. For this reason, discussion on the mechanisms for induction of dominant-lethal mutations and heritable translocations is restricted to stages in which both endpoints are known to be inducible - i.e., melotic and postmeiotic male germ cells.

Because dorinant-lethal mutations an-i heritable transiocations are both endpoints of chronosome breakage events and because ionizing radiations produce ther simultaneously in the same refotic and postmelotic gorm cell stages, it was natural to assume in the beginning that production of these two endpoints involves the same initial events that randomly result in symmetrical (heritable transiocations) and asymmetrical exchanges and deletions (dominant-lethal mutations). This general belief was strengthened by the observations that the alkylating agents studied in the beginning, 1.e., TEM and EMS, not only Induced both endpoints but the respective rates of induction were positively correlated in dose-response studies (Cattanach, 1957; Cattanach, Pollard and Jackson, 1968; Generoso et al., 1974; Matter and Generos, 1974; Generoso, Ca1n and Huff, 1978 ). To date, ho sever, new information (1) strongly indicates that the chemical induction of these two endpoints does not necessarily share the same mechanism 
and (2) provides an insight on the possible molecular events that lead to the production of dominant-lethal mutations and heritable translocations.

With respect to alkylating chemicals, it is reasonable to assume that alkylation of DNA is the initial step that leads to aberration formation. [It should be pointed out that Sega and Owens (1978) associzted protamine alkylation to dominant-lethal effects of EMSI The challenge, however, is determining which specific target sites are responsible for the formation of various types of aberrations. This is a difficult problem because there js a multitude of reactive sites in the DNA molecule and it has not been possible to effect binding only on any single target site in namalian germ cell chromosomes. Thus, at best, interpretations of the most likely adducts responsible for induction of dominant-lethal mutations and heritable translocations cones from association between genetic data and what is known about binding with DNA and about the properties of various adducts.

Unlike the old belıef, dominant-lethal mutations and heritable translocations are not alrays induced at the same relative rates (Table 5 ). Among compounds studied in our laboratory over the years, IMS, BaP and ENU were found to be effective in Inducing dominant-lethal mutations but induce very few or no heritable translocations at the same gern cell stages. This is in contrast to the effects of EMS, MAS, TEM, EtO, MNU and cyclophosphamide, all of which are effective in inducing both endpoints. This finding suggests that the primary lesions that IMS, BaP or ENU induced that resulted in dominant-lethal mutations are different from those that resulted in heritable translocations. In other words, the simple interpretation that the same mechanisn is responsible for the random production of dominant-lethal mutations and heritable translocations is not always correct. 
It was concluded in previous reports (Generoso et al., 1979, 1982;

Generoso, 1982) that the relative rates at which dominant-lethal mutations and heritable translocations are produced from chemicai treatment of meiotic and postmeiotic male germ cells depend upon the stability of alkylation products with DNA. Heritable translocations are induced by chemicals at a high rate relative to dominant-lethal mutations when the corresponding alkylation products are converted into interchanges prior to the first postfertilization chromosomal division, and chemicals whose reaction products perstst to the time of first chromosonal division, or possibl; even to subsequent early cleavage divisions, induce mainly the types of aberrations that lead to dominant lethality. Further, heritable translocations arise primarily frot chronosome-type exchanges while dowinant-lethal mutations arise from both chromosome- and chromatid-type aberrations. For chemicals like IMS, ENU and BaP dominant-lethal mutations appear to come primarly from chromatid-type aberrations. 'ltus, chromosome- and chrcmatid-type aberrations are associated with unstable and stable reaction products, respectively. The question, then, is what are the corresponding DNA target sites?

We have stated aarlier that our interpretation of the likaly adducts responsiblu for the production of dominant-lethal mutations and herttable translocation will huve to be made Erom assocfation between genetic and molecular data. In Table 3 one can see the compounds for which genettc and DNA binding data are avallable. The chenicals that are effactive in inacing heritable translocations (EMS, MMS, MNU and EtO) alkylate primarily the N-7 position of guantne. The chemicals that are Ineffective in inducing heritable translocations but are effective in inducing dominant-lethal mutations (IMS and ENU) alkylates primarliy the oxygen of the phosphate backione (forming 
phosphotriesters) and oxygen in bases, such as $0-6$ position in guanine, and very little alkylation of the nitrogen positions. Consisient with the stability interpretation, N-7 alkyl guanine adducts are not stable and are lost via hydrolysis resulting in the formation of apurinic sites. Alkylation products with oxygen of bases and phosphotriesters, on the other hand, are highly stable. Thus, heritable translocations are associated with unstable $\mathrm{N}-7$ alkylguanine and, likely, with $\mathrm{N}-3$ alkyladenine as well since the latter is also highly unstable.

There is evidence that the process of chronosone exchange involved in heritable translocations takes place after sperm entry (Generoso et al., 1981) and that it is necessary for the unstable adducts to be transformed into intermediate lesions, perhaps into apurinic sites, befcre fertilization in order for this process of exchange to take place (Generoso et al., 1982).

The unstable adducts could also lead to dominant lethality through formation of chromosome-type asymmetrical exchanges and deletions but the stable oxygen alkylations are associated primarily with the production of dominant-lethal mutations. After fertilization the stable adducts in the rale genome are efther repaired by the egg (see section II-D.) or lead to chromatid-type aberrations.

Finally, it is inherent in our interpretation of the mechanisms that the production of $r^{\prime}$ :omosome - and chromatid-type aberrations are not necessarily mutually exclusive. On the contrary, it allows for both classes tr be produced at relative rates that may differ from one mutagen to another, depending upon the array of DNA adducts produced. 
V. REFERENCES

1. Adler, Ilse-Dore (1974) Comparative cytogenetic study after treatment of mouse spermatogonia witt mitomycin C, Mutation Res., 23, 369-379.

2. Auerbach, C. A., and D. S. Falconer (1949) A new mutant in the progeny of mice treated with nitrogen tidstard, Nature, 163, 678-679.

3. Bateman, A. J. (1960) The induction of dominant lethal mutations in rats and mice with trlethylenemelamine (TEM), Genet. Res., 1, 381-392.

4. Burki, $K_{2}$, and $w$. Sheridan (1978) Expressinn of TFM-induced damage to postmeiotic stages of spernatogenesis of the nouse during early embryogenesis. II. Cytological investfgations, Mutation Res., 52, 107-115.

5. Cacheiro, N. L. A. (1977) Cytological studies of sterility in sons of male mice treated wfth TEM in postspermatogontal stages, Genetics, $86,9-10$.

6. Cacheico, N. L. A., I. B. Russell, and H. S. Startout (1974)

Translocations, the predominant cause of total sterility in sons of mice treated with mutagens, Genetics $76,73-91$.

7. Sattanach, B. M. (1957) Induction of translocations in nice by triethylenemelamirs, Nature, 180, 1364-1365.

8. rottanach, B. M., and R. G. Edwards (1958) The efrects of triethylenemelamine on the fertility of male mice, Proc. Roy. Soc. Edinb. B, $67,54-64$.

9. Cattanach, B. M., C. E. Pollard, and J. 4. Jackson (1968) Ethyl methanesulfonate-induced chronosome breakage in the mouse, Mutation Res." $6,297-307$

10. Fhling, U. H. (1971) Compartson of radiation- and chemically induced dominant-lethal mutations in male mice, Mutation Res. 11, 35-44. 
11. Ehling, U. H., and H. V. Malling (1968) 1,4-Di(methane-sulfonoxy) butane (Myleran) as a mutagenic agent in mice, Geretics, 60, 174-175.

12. Ehling, J. H., R. B. Curming, and H. V. Malling (1968) Induction of dominant-lethal mutations by alkylating agents in male mice, Mutation Res., $5,417-428$

13. Ehling, U. H*, D. G. Doherty, and H. V. Mal11ng (1972) Differential spermatogenic response of mice to the induction of drainant-lethal mutations by n-propyl methanesulfonate and 1sopropyl methanesul: onate, Mutation Res., 15, 175-184.

14. Ehrenberg, L., K. D. Hiesche, S. Osterman-Golkar, and X. Wennberg (1974) Evaluatton of genetic risks of alkylating agents: tissur doses in the mouse fron alr contaninated with ethylene oxide, Mutation Res., 24, 83-103.

15. Falconer, D. S., B. M. Slizynskl, and C. Auerbach (1952) Genetical effects of ritrogen mustard in the house mouse, J. Genet., 51, 81-89.

16. Generoso, W. M., and W. L. Russel1 (1969) Strain and sex variations in the sensittuity of mice to dominant-lethal induction with ethyl methanesulfonate, Mutation Res., 8, 589-598.

17. Generoso, W. M., W. I. Russell, S. W. Huff, S. K. Stout, and D. G. Gosslee (1974) Effects of dose on the induction of dominant-lethal mutations and heritable translocations with ethyl methanesulfonate in male rulce, Genetics, 77, 741-752.

18. Generoso, W. M., R. J. Preston, and J. G. Brewen (1975) 6-Mercaptopurine, an inducer of cytogenetic and dominant-lethal effects in premeiotic and early meiotic germ cells of male mice, Mutation Res., 28, 437-447.

19. Generoso, W. M., K. T. Caln, S. W. Huff and D. G. Gosslee (1978) Heritable translocation test in mice, In, Chemical Mutagens - and Methods for Their 
Detection, Vol. 5, edited by A. Hollaender and $\mathrm{Y}$. J. de Serres, Plenum Press, New York, London pp. 55-77.

20. Generoso, W. M., Katherlne T. Cain, Sandra W. Huff, (1973b) Inducibility by chemical mutagens of heritatile translocations in nale and fenale germ cells of mice, In, Advances in Modern Toxicology, Voi. 5 edited by W. G, Glamm and M. A. Mehlman, Hernisphere Publishing Corporation, Washington, D.C., London pp. 109-129.

21. Seneroso, W. M., K. T. Cain, M. Krishna, and S. W. Huft (1979a) Genet1c lestons Induced by chenicals in spermatozoa and spermatids of mice are repaired in the egg, Proc. Nat1. Acad. Sci., IJSA, 76, 435-437.

22. Generoso, W. M., S. W. Huff, and K. T. Cain (1979b) Relative rates at which doninant-lethal mutations and heritahle translocations were induced by alkylating chemicals in postmeiotic male germ cells of mice, Genetics, 93, $163-171$

23. Coneruso, W. M., y. B. Bishop, D. G. Gosslee, G. W. Newell, C. J. Sheu, and E. von Halle (1980) Heritable translocation test in mice: A report of the "GFNE-TOX" program, Mutation Res., 76, 191-215.

24. Generoso, W. M., X. T. Cain, M. Krishna, E. B. Cunningham, and C. S. Hellwig (1981a) Evidence that chromosome rearrangements occur after fertilization following postmeiotic treatment of male nice germ cells with E.MS, Mutation Res., 91, 137-140.

25. Generoso, W. M., M. Krishna, K. T. Cain, and C. W. Sheu (1981b) Cotpartson of two methods for detecting translocation heterozygoses in mice, Mutation Res., 81, 177-186.

26. Generoso, W. M., K. T. Cain, C. V. Cornett, E. W. Russe11, C. S. Hellwig, and C. $\because$. Horton (1982a) Difference in the ratio of dominant-lethal 
mutations to herltable translocations produced in monse spermatids and Eully mature sperm after treatment wich triethylenemelamine (FEM), Genetics $100,633-540$.

27. Generoso, H. M. (i982b) A possible mechanism for chemfcal induction of chromosome aberrations in wale meiotic and postmeivtio germ cells of mice, Cytogenet. Cell Genet., 33, 74-80.

28. Hitotsumachi, S., and Y. Kikuch1 (1977) Chromosone aberra' .s and rominant lethality nf mouse embryus after paternal treat?ent with triethylenemelamine, Mutation Res., 4?, 117-124.

: Jackson, H., and M. Bock (1955) Effect of triethylene melamine un the fertility of rats, Nature, 175; 1037-1038.

30. Koller, P. C. (1944) Segmental interchange in mice, Genetics, 29, 247-263.

31. Koller, P. C., and C. A. Auerbach (194]) Chronosome breakage and Gterility in the morse, Nature, 148, 501-502.

32. Lawley, P. D., D. J. Orr, and M. Jarman (1975) Isolation and identiffcation of products fron alkylation of nucleic acjds: Ethyl- and isopropylpurines, Biocher. J., 145, 73-84.

33. Luippold, H. E., P. C. Gooch, and J. G. Brewen (1978) The production of chronosomi aberrations in various mamalian cells by triethylenemelamine, Genetics, 88, 317-326.

34. Matter, B. E., and W. M. Generoso (1974) Effects of dose 3 ..e induction of doninant-lethal mutations with triethylenemelamine in wale mice, Genetics 77, 753-763.

35. Matter, B. E., and I. Jaeger (1975) Premature chromosone condensation, structural chromosome aberrations, and micronuclei in early mouse embryos after treatment of parental postmeiotic germ cells with triethy.ene- 
melamine. Possible mechanism for cherically induced doninant-lethal mutations, Mutation Res., 33, 251-260.

36. Ray, V. A., and M. L. Hyneck (1973) Some primary consideration in the Interpretation of the dominant-1ethal assay, Environ. Health Perspect., 6, $27-36$

37. Russel1, L. B., and C. S. Montgomery (1969) Comparat1ve studies on $X$-autosume translocations in the mouse. I. Orlgin, viability, fertility and weight of five (TX; 1)S', Genet1cs, 63, 103-120.

38. Russe1l, W. L. (1954) Genettc effects of radiation in mamals. In Radiation Biology, Ed. by A. Hollaender, Mccraw-Hill, New York, pp. 825-859, Vo1. 1 .

39. Stga, G. A., and J. G. Owens (1973) Ethylation of DNA and protamine by ethyl methanesulfonate in the germ cells of male nice and the relevancy of these molecular targets to the Induction of dominant lethals, Mutation Res., 52, 87-106.

40. Selbj, P. B. (1979) Radiation-induced skeletal mutations In mice: mutation rate, characteristiss, and usefulness in estimating genetic hazard to humans from radiation, In Radiation Research, Proceedings of the 6th Tntern. Cong. of Radia. Res., edited by S. Okada, M. Imamura, T. Terashima, and H. Yamaguchi, Toppan Printing Co., Tokyo, Japan, Isp. 537-544.

41. Singer, B. (1982) Mutagenesis from a cherical perspective: nucleic actd reactions, repair, translation, and transcription, In Basic Life Sclences, Vol. 20, Molecular and Cellular Mechanisms of Mutagenesis, edited by J. F. Jemontt and W. M. Generoso, Plenum Press, New York, pp. 1-42.

42. Snell, G. D. (1933) Genetic changes in mice induced by X-rays, Am. Naturalist, 67, 24 . 
43. Snell, G. D. (1934) The production of translocations and mutations in mice by means of X-rays, Am. Naturalist, 68,178 .

44. Snell, G. D. (1935) The induction by X-rays of hereditary chai:ses in mice, Genit1cs, 20, 545-567.

45. Sne11, G. D. (1941) Linkage studies with induced translocations in mice, Genetics, 26, 169.

46. Snel1, G. D. (1946) An analysis of translocations in the mouse, Genetics, $31,157-180$.

47. Steinberger, E., W. D. Nelson, A. Boccabe1la, and W. J. Dixon (1959)

A radionimetic effect of TEM on reproduction in the male rat, Endocrinology, 65, 40-50. 
Table 1. Nose-effect of EMS in the induction of domfnait-lethal mutatons in mate mice ${ }^{2}$

\begin{tabular}{|c|c|c|c|c|c|c|c|}
\hline \multirow{2}{*}{$\begin{array}{l}\text { Dose } \\
(\mathrm{mg} / \mathrm{kg})\end{array}$} & \multirow{2}{*}{$\begin{array}{l}\text { No. of } \\
\text { mated } \\
\text { femalesb }\end{array}$} & \multirow{2}{*}{$\begin{array}{l}\text { No. of } \\
\text { pregnant } \\
\text { females }\end{array}$} & \multirow{2}{*}{$\begin{array}{c}\text { 'Total } \\
\text { implants } \\
\text { among, fertile } \\
\text { females } \\
\text { (avg) }\end{array}$} & \multirow{2}{*}{$\begin{array}{c}\text { Ljving } \\
\text { embryos } \\
\text { among fertile } \\
\text { females } \\
\text { (avg) }\end{array}$} & \multirow{2}{*}{$\begin{array}{l}\text { Dead } \\
\text { Implants } \\
\text { (percent) }\end{array}$} & \multicolumn{2}{|c|}{$\begin{array}{l}\text { Living, embryos as } \\
\text { percent of controls }\end{array}$} \\
\hline & & & & & & $\begin{array}{c}\text { Among } \\
\text { fertile } \\
\text { females }\end{array}$ & $\begin{array}{c}\text { Among al } 1 \\
\text { mated } \\
\text { females }\end{array}$ \\
\hline Control & 22. & 22 & 7.7 & 7.1 & 7 & - & - \\
\hline 100 & 25 & 22. & 7.5 & $i n$ & 7 & 99 & 86 \\
\hline 150 & 21 & 21 & 7.2 & $5.9^{c}$ & 19 & 83 & 82 \\
\hline 200 & 27 & 25 & $6.4^{\text {d }}$ & 3.5 & 45 & 49 & 46 \\
\hline 250 & 29 & $15^{\mathrm{C}}$ & $4.5^{c}$ & 1.1 & 71 & 15 & 8 \\
\hline 300 & 21 & 1 & $2 . n$ & 0 & 100 & 0 & 0 \\
\hline
\end{tabular}

a From Generoso et al., 1974 .

${ }^{b} 11$ matings occurred $6.5-7.5$ days after treatment.

$c_{p}<0.01$ for comparison with control.

$d_{P}<0.05$ for comparison with cantrol. 
Table 2. Differences between stock of male mice in response to dominant-lethal effects of EMS.

\begin{tabular}{|c|c|c|c|c|c|c|}
\hline Treatment & Stock of males ${ }^{a}$ & $\begin{array}{l}\text { Number of } \\
\text { mated } \\
\text { females }\end{array}$ & $\begin{array}{l}\text { Number of } \\
\text { pregnant } \\
\text { females }\end{array}$ & $\begin{array}{c}\text { Number of } \\
\text { 11ve embryos } \\
\text { (ave) }\end{array}$ & $\begin{array}{c}\text { Dead } \\
\text { 1mplants } \\
(\%)\end{array}$ & $\begin{array}{l}\text { Dominant } \\
\text { lethals } \\
(\%)\end{array}$ \\
\hline $\mathrm{EMS}^{\mathrm{C}}$ & $(\mathrm{C} 3 \mathrm{H} \times \mathrm{C} 57 \mathrm{BL}) F_{1}$ & 39 & 36 & 5.4 & 47 & 50 \\
\hline \multirow[t]{3}{*}{$(200 \mathrm{mg} / \mathrm{kg})$} & $(101 \times \mathrm{C} 3 \mathrm{H}) \mathrm{F}_{1}$ & 37 & 35 & 2.8 & 68 & 74 \\
\hline & $(\operatorname{SEC} \times \operatorname{C5} 7 \mathrm{BL}) \mathrm{F}_{1}$ & 45 & 43 & 5.7 & 44 & 47 \\
\hline & T-gtock & 43 & 39 & 7.5 & 30 & 30 \\
\hline \multirow[t]{4}{*}{ Control $^{\mathrm{d}}$} & $(\mathrm{C} 3 \mathrm{H} \times \mathrm{C} 57 \mathrm{BL}) \mathrm{F}_{1}$ & 23 & 22 & 10.2 & 9 & \\
\hline & $(101 \times \mathrm{C} 3 \mathrm{H}) \mathrm{F}_{1}$ & 18 & 17 & 10.6 & 7 & \\
\hline & $(\mathrm{SEC} \times \mathrm{C57BL}) \mathrm{F}_{1}$ & 21 & 19 & 10.8 & 2 & \\
\hline & $T-s$ tock & 23 & 19 & 11.5 & 4 & \\
\hline
\end{tabular}

$a_{\text {Females used were from }(C 3 H \times C 57 B L) F}$ stock.

${ }^{\mathrm{b}}$ Calculated using the formula: $\%$ D.L. $=\left[1 \frac{\text { average number of } 11 \mathrm{ving} \text { embryos (experimental) }}{\text { average number of } 11 \mathrm{ving} \text { embryos }(\operatorname{cont} r o 1)} \times 100\right.$.

All calculations were based on the pooled control average of 10.8 from all stocks.

cTreatment to fertilization interval - $61 / 2$ to $91 / 2$ days, EMS was administered as a single $1 . p$. 1nfection.

${ }^{d}$ Control females were mated $4 \frac{1}{2}$ to $71 / 2$ days after injection. They were also used as contemporary control for another study. 
Table 3. Strain Differences in Reproductive Performance of Fenale Mice ${ }^{a}$

\begin{tabular}{lccccc} 
Strain & $\begin{array}{c}\text { Number of } \\
\text { mated } \\
\text { females }\end{array}$ & $\begin{array}{c}\text { Fertile } \\
\text { matings } \\
(\%)\end{array}$ & $\begin{array}{c}\text { Number of } \\
\text { implants } \\
\text { (ave) }\end{array}$ & $\begin{array}{c}\text { Number of } \\
\text { living } \\
\text { embryos } \\
\text { (avg) }\end{array}$ & $\begin{array}{c}\text { Dead } \\
(\%)\end{array}$ \\
\hline T-stock & 65 & 94 & 8.5 & 6.8 & 20 \\
$(10 \mathrm{I} \times \mathrm{C} 3 \mathrm{H}) \mathrm{F}_{1}$ & 51 & 96 & 7.3 & 6.9 & 6 \\
$(\mathrm{SEC} \times \mathrm{C57BL}) \mathrm{F}$ & 40 & 83 & 9.8 & 9.3 & 5 \\
\hline
\end{tabular}

${ }^{3}$ From Generoso and Kussel1 (1969).

${ }^{b}$ These females served as controls of an experiment.

Mating was indicated by the presence of vaginal plug. 
Table 4. Average Fertility of Partally Sterile Male Translocation Heterozygotes Produced fron Postmeiotic Treatment of Male Pice

\begin{tabular}{|c|c|c|c|c|c|}
\hline Treatment & Class & $\begin{array}{l}\text { No. of } \\
\text { males } \\
\text { tested }\end{array}$ & $\begin{array}{l}\text { No. of } \\
\text { Implants b } \\
(a \vee g)\end{array}$ & $\begin{array}{l}\text { No. of } \\
\text { living } \\
\text { embryos } b \\
\text { (avg) }\end{array}$ & $\begin{array}{c}\text { Dead } \\
\text { tmplants } \\
(\%)\end{array}$ \\
\hline \multirow[t]{2}{*}{$X-r a y$} & Partially sterfle & 30 & 9.1 & $3.9(43 \%)^{c}$ & 57 \\
\hline & Normal & 39 & 9.6 & 9.0 & 6 \\
\hline \multirow[t]{2}{*}{ TEM } & Partially sterile & 119 & 9.2 & $4.2(44 \%)^{c}$ & 54 \\
\hline & Normal & 69 & 10.0 & 9.5 & 5 \\
\hline \multirow[t]{2}{*}{ EMS } & Partially sterile & 98 & 9.3 & $4.5(44 \%)^{c}$ & 58 \\
\hline & Normal & 39 & 10.7 & 10.2 & 5 \\
\hline
\end{tabular}

arom Generoso et al. (1978b).

${ }^{b}$ Six pregnancies were analyzed for each partially sterile male and three for each normal male. 
Table 5. Association Between DNA Adducts and Inducibility of Dominant-Lethal Mutations and Heritable Translocitions

\begin{tabular}{|c|c|c|c|c|}
\hline \multirow{2}{*}{ Mutagen } & \multicolumn{3}{|c|}{ Induction of } & \multirow{2}{*}{$\begin{array}{l}\text { Alkylation at } \\
\text { N-7 Guantine }\end{array}$} \\
\hline & $\begin{array}{l}\text { Dominant } \\
\text { Lethals }\end{array}$ & $\begin{array}{r}\text { Her } \\
\text { Trans }\end{array}$ & $\begin{array}{l}\text { it table } \\
\text { slocations }\end{array}$ & \\
\hline $\mathrm{BaP}$ & High & Not & Detected & - \\
\hline $\mathrm{IMS}^{\mathrm{b}}$ & High & & Low & 7.6 \\
\hline ENU $^{b}$ & High & & Low & 11.5 \\
\hline $\mathrm{MNU}$ & High & & High & 67.0 \\
\hline MMS & High & & High & 83.0 \\
\hline EMS & High & & High & 65.0 \\
\hline Eto & High & & High & 90.0 \\
\hline TEM & Irigh & & High & - \\
\hline Cycl'phosphamide & High & & High & - \\
\hline
\end{tabular}

apercentage of total alkylation in DNA (Ehrenberg et al., 1974; Lawley et al., 1975; Singer, 198?).

bost of the reaction products are in oxygen of the phosphate backbone. oxyien in bases are also alkylated to a lesser extent. 